\title{
Miodrag Kalčić
}

Radićeva 26, HR-52100 Pula

miokalkin@gmail.com

\section{Počeci kinofikacije Pule (do početka Velikoga rata): prvi puljski stalni kinematografi i prvo erotsko kino}

\author{
Izvorni znanstveni rad | Original scientific paper \\ UDK 791(497.571Pula)«1906/1914« \\ 791.226(497.571Pula)(091) \\ Primljeno | Received: 9. VIII. 2016.
}

\section{Izvadak}

Autor istražuje početke kinoprikazivačke djelatnosti u Puli od 1906. do 1914. godine. $U$ radu se propituju prijepori i nedoumice glede fluidnosti i nedefiniranosti termina (pojmova) polustalno i stalno kino na primjerima prva dva puljska kinematografa. Ispravljaju se propusti u nazivima i počecima filmskih projekcija u pojedinim puljskim kinima, upozorava na izostavljanje prvih kinematografa Pule u svim relevantnim hrvatskim enciklopedijama, knjigama, zbornicima i sličnim publikacijama o povijesti filma u Hrvatskoj te ukazuje na specifičnost repertoara (drugoga) kina Edison koji je često na programu imao „crne večeri” (serate nere, Herrenabende), što Pulu čini filmski specifičnim gradom, a kinematograf žanrovski određuje kao prvo erotsko kino.

\footnotetext{
Abstract

The paper explores the beginnings of movie screening activities in Pula from 1906 to 1914 . The author deals with controversies and doubts regarding the imprecision of the terms semi-permanent and permanent cinema by drawing on examples from the first two cinemas in Pula. He corrects the errors in the names and origins of film screenings in certain theatres in Pula, warns of the omission of the first cinemas in Pula in all relevant Croatian encyclopaedias, books, anthologies and similar publications on the history of film in Croatia, and shows the peculiarity of the repertoire of the (second) cinema Edison which often features the so called "black evenings" (serate nere, Herrenabende), making it the first erotic cinema of Pula and present day Croatia.
} 
Ključne riječi: Pula, početak kinofikacije, putujući kinematografi, polustalno kino, stalno kino, erotsko kino, erotski film, pornografski film, „crne večeri” (serate nere) Key words: Pula, the beginning of cinemafication, traveling cinemas, semi-permanent cinema, permanent cinema, erotic cinema, erotic movies, pornographic film, "black evenings" (serate nere)

\section{Uvod: fijasko u Politeami Ciscutti i putujuća kina u Puli}

Zabavljači (mađioničari, klaunovi, akrobati, žongleri, iluzionisti, dreseri, recitatori, komedijaši, pantomimičari, pjevači, glazbenici) i raznoliki skupni spektakli (cirkusi, putujuće kazališne družine, skupine komičara, zabavljačke grupe, glazbeni sastavi, zborovi) putovali su i kružili Europom, od grada do gradića, od mjesta do sela, stoljećima. Na samom kraju 19. stoljeća priključuju im se i putujući, relativno jeftini kinematografi (dovoljno je nabaviti projekcijski uređaj i filmove). Film, jedini od svih umjetnosti, slavi rođendan, poznaje datum svoje prve komercijalne kinematografske projekcije (estetsku kategoriju dostigao je kasnije, a osnovna mu je osobina ostala jednaka kako je i započeta, masovna zabava), iako se eksperimentiralo i projiciralo živuće fotografije puno prije službenoga rođendana filma. Francuska braća Louis i Auguste Lumière (s takvim signifikantnim i indikativnim prezimenom, njuejdžovski rečeno, bili su predodređeni za slikopisnu djelatnost [franc. lumière $=$ svjetlost $]$ ) objedinila su poznate eksperimentalne dosege i dovršila izum te konačno komercijalizirala kinematografski sustav snimanja, kopiranja i (naplaćivanja) projekcije filma na zaslonu u dvorani pred gledateljima, prvi put u Indijskom salonu Grand Caféa u Parizu 28. prosinca 1895. (prodane su 33 ulaznice po jedan franak). Nakon prve pariške kinematografske predstave mehanizam živućih fotografija (zabavnih gibljivih slika) tehnološki je unaprijeđen i kao takav ubrzo posjećuje sva europska središta, i bilo je samo pitanje vremena kada će se optička iluzija iz Trsta (gdje je prva kinematografska predstava bila 8 . srpnja 1896.) ${ }^{1}$ spustiti niz istarski poluotok do glavne austro-ugarske ratne luke Pule.

Izazovnosti živućih fotografija (iluzije života) nisu mogli odoljeti ni plebs, ni aristokracija, ni carevi. „U aprilu (točnije, 17. travnja, op. a.) 1896. u Beču, car Franjo Josip, potaknut hvalama upućenim predstavama braće Lumière, posjećuje predstavu, povlađuje i šalje pronalazačima svoje

1 Dejan Kosanović, Trieste al cinema (1896-1918) (dalje: Trieste al cinema), trad. di Sergio Turconi, Gemona del Friuli 1995., 21. 
najtoplije čestitke." ${ }^{\text {22 }}$ Razgranata mreža angažiranih Lumièreovih kinoprikazivača širila je urbanim krvotokom Europe zaraznu zabavu živućih fotografija brzinom nenadane, ali radosne ciklone. Demokratska dostupnost i sveprisutnost kinematografije kao jeftine zabave u svim slojevima društva nije se nigdje - ni na dvorovima, ni u gradovima, ni u zabavištima, ni na sajmištima - mogla izbjeći.

Popularnost masovne zabavne novotarije gibljivih slika, poput ostalih novotarija takve provenijencije koje su redovito stizale u austrijsku glavnu ratnu luku, po navadi je trebala biti demonstrirana i obznanjena u puljskome zabavištu i kazalištu. I doista, u subotu, 21. studenoga 1896., samo deset mjeseci i tri tjedna nakon Pariza, najavljen je u Politeami Ciscutti kinematograf, cinématographe, čuveni Lumièreov uređaj za projekciju živućih slika: na programu je u Puli još jedna, za ono doba posvema nova i svježa zabava, fantastična atrakcija - kinematografska predstava. „Danas, u subotu, i sutra, u nedjelju, otvaraju se vrata našega kazališta kinematografu koji dolazi iz Trsta. Profesor vitez de Horney dolazi prvi put ovamo, u Pulu, i nada se da će biti počašćen mnogobrojnim posjetom. “s Posjet je uistinu bio masovan, jurnuli su Puljani (svih klasa i staleža) po ulaznice, nahrupili i napunili Ciscutti jer imali su priliku po prvi put i među prvima u Europi prisustvovati projekciji „živućih fotografija“ ili „pokretnih slika“ (fotografie viventi, bewegte Bilder, Filmbildern), kako se tada najradije nazivala tehnološka novotarija (tek kasnije nazvana filmom) usmjerene svjetlosti koja je izlazila iz čudesna kinematografa i na ekranu projicirala film (pokretni svijet), popularnom znanstveno-tehničkom čudu, tehnološkoj atrakciji bez premca koja je netom preplavila gotovo sve veće europske gradove i tek ušla u Austro-Ugarsku Monarhiju.

Zvučne i laskave znanstvene titule „profesora viteza de Horneya, profesora fizike Akademije znanosti u Madridu, počasnoga člana Društva prirodnih znanosti u New Yorku i Petrogradu, nositelja Medalje za zasluge u znanosti (Pour les Mérites des Sciences)..." samo su malobrojne naivne Puljane mogle u prvi mah impresionirati; većini je iz prijašnjih naracijskih panorama podozrivo zvučalo (po svemu) izmišljeno titulirano ime viteza

2 Branko Belan, Sjaj i bijeda filma, Zagreb 1966., 18.

3 „Oggi sabato e domani domenica, si riapriranno i battenti del nostro teatro per dare accesso al cinematografe, proveniente da Trieste. Il professor cav. de Horney intraprende per la prima volta il viaggio qui a Pola e spera di essere onorato di numeroso concorso.“ „Cronaca cittadina: Politeama Ciscutti“, L'Eco di Pola, 21. studenoga 1896.

4 „Il celebre M. cav. de Horney“, L'Eco di Pola, 28. studenoga 1896. 
de Horneya, ali u pitanju je bila europska popularna novost - kinematograf. Iza viteškoga imena krio se dvojac, trgovac ogrjevnim drvom i ugljenom Max Karreiter ${ }^{5}$ i novinar, redaktor i kazališni impresario Angelo Curiel $^{6}$, vlasnici putujućega kinematografa iz Trsta koji, u potrazi za brzim zgrtanjem novca, putuju Carevinom (Cislajtanijom) i prodaju kvaziznanstvena predavanja popraćena osvijetljenim fotografijama na staklu, „fotoplastičnim panoramama“, tada čestim fotopredstavama s ondašnjim dijapozitivima, i prvim kinematografskim projekcijama. Tako su i Puli 21. studenoga 1896., poslije glazbeno-zabavnoga pretprograma Mornaričkoga orkestra i orkestra Operetnoga društva, podvalili tobože stručan program sastavljen od tematskih predavanja o arheološkim iskapanjima i čovječjem tijelu koje je puljska publika dobrano izviždala, duhovitim upadicama ismijala i izvrgla ruglu (na de Horneyevo opetovano nastavljeno nepripremljeno predavanje prepuno pogrešaka i očitoga nepoznavanja ljudskoga tijela, puljski su obrazovaniji gledatelji, časnici i građani, već umorni od stalnoga ispravljanja predavača i zviždanja, sarkastično uzvikivali samo „odlično, bravo, bravo...“ i frenetično pljeskali), nestrpljivo iščekujući ono zbog čega je zapravo došla, projekciju „Živućih fotografija“.

Prva puljska kinematografska projekcija gibljivih slika ispala je totalni fijasko. Karreiterovo i Curielovo projiciranje pokretnih slika, za što su unajmili prikazivačkoga, kinematografskog stručnjaka iz Pariza, gospodina Madesnyja, jedva se razabiralo, tek zamjećivalo, bilo je nejasno, mutno, nedovoljno osvijetljeno, tamno, neoštro, neuredno, isprekidano i pokatkad okrenuto naglavce. Strpljivi gledatelji očekujući makar jednu jedinu ispravnu projekciju, makar jedan kratak gledljiv filmski geg koji nikako da se pojavi, na koncu su izgubili strpljenje, većina ih je ustala, odjenula „ogrtače te gunđajući, zijevajući i zviždeći krenula prema vratima. No, na glavnom ulazu

5 „Max Karreiter, trgovac iz Trsta (?), od 1896. godine zajedno s Angelom Curielom, kao suvlasnikom kinematografske aparature, pokazivao filmove u Trstu, zatim Puli (prva filmska projekcija studenoga 1896.), Celju, Mariboru, Opatiji, Zadru, Šibeniku, Sarajevu (prva filmska projekcija srpnja 1897.), zatim ponovno u Trstu. Krajem devedesetih godina prestao se baviti prikazivanjem filmova." Dejan Kosanović, Leksikon pionira filma i filmskih stvaralaca na tlu jugoslavenskih zemalja 1896 - 1945 (dalje: Leksikon pionira filma), Beograd 2000., 108.

6 „Angelo Curiel, novinar, kazališni impresario i vlasnik putujućeg kinematografa iz Trsta, od 1896. godine zajedno s Maxom Karreiterom prikazivao filmove u Trstu i po našim krajevima - u Puli (prva filmska projekcija studenoga 1896.), Celju, Mariboru, Opatiji, Zadru, Šibeniku, Sarajevu (prva filmska projekcija srpnja 1897.) i kasnije ponovno u Trstu i nekim drugim gradovima Hrvatske i Slovenije. Početkom dvadesetog stoljeća Curiel, pored drugih aktivnosti, bavi se i dalje organiziranjem filmskih predstava (bez Karreitera), a 1917. i 1918. organizira stalno kino u kazalištu Armonia u Trstu." Isto, 122.

7 U Istarskoj enciklopediji (ur. Miroslav Bertoša i Robert Matijašić, Zagreb 2005.) ni pod enciklopedijskom jedinicom „film“ (224), koju potpisuje novinar Mate Ćurić, ni pod jedinicom „kinematografija“ (387-388), koju zajedno potpisuju publicist Giuseppe Orbanich i novinar Mate Ćurić, ni ikojoj drugoj, ne postoji datum prve filmske projekcije u Puli (i Istri). 
još uvijek su se izdavale ulaznice. Nastao je neopisiv metež. Nikome nije bilo jasno da li je ono što se prikazuje ujedno i posljednja slika, je li predstavi konačno kraj. Posjetitelji su izlazili i ulazili, galamili i tražili povrat novca za tako lošu predstavu. Nakon tisuću pitanja i odgovora, nakon tisuću okretaja i promenada po kazalištu doznalo se da je predstava zaista zavr-

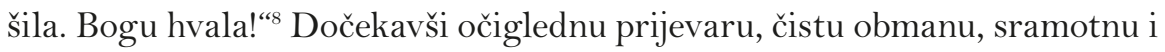
prijezira vrijednu toliko iščekivanu predstavu „živućih fotografija“, 9 Puljani su nezadovoljni, mrzovoljni i ljuti, burnim negodovanjem i ponekom sočnom psovkom napustili Ciscutti. Novac im nije vraćen.

Najavljena sutrašnja rasprodana predstava, nedjeljna repriza - nije preostalo drugo - otkazana je. Vlasnici putujućega kinematografa, šarlatanski impresariji, prevaranti i varalice, Max Karreiter i Angelo Curiel posvađali su se sa stručnjakom iz Pariza zaduženim za prikazivanje živućih fotografija, odmah sutradan ujutro otputovali iz Pule i promptno otkazali, pored nedjeljne puljske reprize, i unaprijed planiranu istovjetnu puljsku predstavu, Cinematografo di Horney, u Gorici. ${ }^{10}$ Puljski kinematografski skandal ubrzo je odjeknuo i izvan Pule, o njemu pišu dnevnici i tjednici u Trstu, Gorici (,predstava u kazalištu Ciscutti bila je prava parodija kinematografije“ $)^{11}$ i ostalim gradovima. No, poslovno uigran kinematografski par ne posustaje od uložene investicije: samo dva tjedna nakon debakla i fijaska u Ciscuttiju, 5. prosinca 1896., u svome gradu, u Trstu (Teatro Filodrammatico), organiziraju sličnu, tehnički nešto uspješniju predstavu s ondašnjim neizbježnim dijapozitivima i kinematografskim projekcijama, proiezioni di cinematografo e di „agioscopio“, ali ovoga puta spretnije i pametnije, bez spomena nepostojećega profesora, viteza de Horneya i gospodina iz Pariza, kojega su najvjerojatnije otpustili. ${ }^{12}$

Gospodin Madesny (uskraćen dogovorenoga honorara) „otkrio je tršćanskim novinarima ${ }^{13}$ da vitez de Horney ne postoji, već da se iza

8 „Il celebre M. cav. de Horney“, L’Eco di Pola, 28. studenoga 1896.

9 Tjedan dana nakon filmskoga fijaska u Ciscuttiju, novinar tjednika L'Eco di Pola prisjeća se puljskoga nestrpljenja i velikog iščekivanja prve kinematografske projekcije u gradu: „Dva, tri dana prije predstave u našem kazalištu razgovaralo se samo o kinematografu, nedavnom pronalasku čuvenoga Američanina Edisona...“, „Il celebre M. cav. de Horney“, L'Eco di Pola, 28. studenoga 1896.

10 Prema dnevniku Corriere di Gorizia (3., 5., 17. i 26. studenoga te 3. prosinca 1896.), „gostovanje kinematografa 'viteza de Horneyja' u Gorici, najavljivano početkom studenoga 1896. kao 'apsolutna novost' za grad, više je puta najavljivano i otkazivano, navodno zbog bolesti 'direktora viteza de Horneyja', te je na koncu i konačno otkazano. Tom prigodom u dnevniku piše do kakvog je skandala došlo u Puli i novinar zaključuje kako je dobro da de Horney nije ni stigao u Goricu. “ Dejan Kosanović, Kinematografske delatnosti u Puli 1896-1918 (dalje: Kinematografske delatnosti u Puli), Beograd-Pula 1988., 18, bilj. 7.

11 Corriere di Gorizia, 26. studenoga 1896.; u: Kosanović, Kinematografske delatnosti u Puli, 16.

12 Kosanović, Trieste al cinema, 28.

13 Il Piccolo della sera, 26. studenoga 1896. 
toga imena kriju Curiel i Karreiter, koje je upozorio da svjetlosni izvor za kinematografsku projekciju u tako velikoj sali nije dovoljno jak, ali oni su inzistirali da se projekcija ipak održi“"14, te se, za razliku od svojih poslodavaca, pokazao uistinu pravim gospodinom i džentlmenom ispričavši se Puljanima za neuspjelu projekciju. „Što se tiče tehničkoga promašaja u Politeami Ciscutti, primili smo dva pisma, jedno gospodina Madesnyja, rukovoditelja kinematografa, kojim se ispričava gledateljima, i gdje napominje da je upozorio svoje impresarije gospodu Karreitera i Curiela kako će aparatura zatajiti i da svjetlost neće imati dovoljnu snagu za predstavu od tri sata (najmanje 15 ampera). ${ }^{15}$ Gospoda su ipak inzistirala, a kada je predstava propala, odbili su isplatiti dogovorenu naknadu gospodinu Madesnyju koji je specijalno iz Pariza došao rukovati kinematografom. U pismu dodaje i da profesor de Horney, toliko razglašen na plakatima, nikada nije ni postojao. Drugo pismo, impresarija Politeame Ciscutti gospodina Alberta Verniera, ${ }^{16}$ odgovara na napis puljskoga dopisnika tršćanskoga tjednika Il Piccolo della sera upitom: "Tko u svom životu nije bio barem jednom prevaren?’. On je to bio prošle subote i pretrpio štetu jer cijeli je utržak spontano predao Ženskom dobrotvornom društvu. "17 Ako već u prvim gibljivim fotografijama zbog tehničkih propusta nisu mogli uživati budući puljski filmofili, barem su profitirale emancipirane i dobrohotne puljske dame.

Polivalentno zabavište (a ponekad i kazalište) Politeama Ciscutti rado je i poslije iznajmljivalo dvoranu (što je bio gotovo jedini izvor prihoda) raznim putujućim kinematografima (i sličnim zabavama i cirkuskim atrakcijama). Iako prva predstava „Živućih fotografija“ nije imala nikakva uspjeha (upravo suprotno), svejedno je filmska zabava u Puli (kao i u cijeloj Carevini) postala masovna pojava (s ondašnjim poprilično kvalitetnim projekcijama) pa je i Ciscutti ubirao pristojnu zaradu od kinematografskih najmova dvorane. $^{18}$

14 Dejan Kosanović, „Ko je bio Angelo Curiel?“, Sineast, 101, Sarajevo 1996., 75.

15 Politeama Ciscutti bila je plinski osvijetljena. Električna je struja uvedena šest godina kasnije (1902.) pa je kinematografska i dijaprojektorska aparatura bila napajana iz posebnoga akumulatora koji je s vremenom gubio jakost i snagu.

16 „Per la pura verità“, L'Eco di Pola, 28. studenoga 1896.

17 Il giovine pensiero, 28. studenoga 1896.; u: Kosanović, Kinematografske delatnosti u Puli, 16.

18 „Politeama Ciscutti, kada je riječ o teatru u najužem smislu, funkcionirala je kao teatro stagione, dakle kao zdanje bez vlastitog ansambla, odnosno prostor koji je stajao na dispoziciji svakome tko je bio voljan platiti najamninu.“ Jelena Lužina-Sladonja, „Obnova scenskog života u NOB-u i nakon oslobođenja, do danas“, Prilozi o zavičaju, 4, 1986., 31. 
U Pulu nedugo poslije kinematografskoga skandala u Politeami, već 20. veljače 1897., iz Beča preko Graza, Trsta i Rijeke stiže Georg Hengl ${ }^{19}$ (i ostaje deset dana, do 2. ožujka), vlasnik kronofotografa (chronophotographe ili talijanski cronofotografo, projekcijski uređaj koji je 1896. patentirao Leon Gaumont, konkurent braće Lumière, a mogao je prikazivati filmove Lumièreovih), te projicira živuće fotografije u salonu-pivnici Silberegger Bierhalle, otkupljenom i preuzetom budimpeštanskom paviljonu Milenijske izložbe podignutom u Šijani, točnije na Šijanskoj poljani (Kaiserwiese). „U salonu Silberegger Bierhalle od sutra, nedjelje i nadalje bit će kronofotograf, uređaj s pokretnim fotografijama koji se pokazao iznimno uspješnim u obližnjoj Rijeci.“20 Uz zveckanje krigla piva, klokot i podrigivanje Puljani su se veselo smijali prvosnimljenim kratkim filmovima (dvadesetak vrlo kratkih filmski gegova, skečeva i dokumentaraca, ili slika, kako su ih tada jednostavno nazivali). ${ }^{21}$ Odmah poslije Pule Georg Hengl s kronofotografom i istim programom putuje za Ljubljanu, gdje već 7. ožujka 1897. ima prve projekcije. ${ }^{22}$ Pula je nakon Šijane definitivno zaražena filmskom zabavom.

Spuštaju se putujući kinematografi redovito niz Istru ili brodovima doplovljavaju do Pule. Koliko je iz puljskih dnevnih i tjednih novina poznato, ukupno su u Puli do Prvoga svjetskog rata, kada su već stasale stalne kinodvorane, bila zabilježena 32 putujuća kinematografa, od kojih je 21 (66 \%) gostovao u Politeami Ciscutti ${ }^{23}$ (stalno se kino u kazalištu otvara tek prosinca 1914.), što, naravno, nije nimalo relevantan podatak jer je zasigurno bilo i drugih putujućih kinematografa (što je tada bio unosan posao) na kraćem proputovanju Pulom (i Istrom) ili kinematografa u sklopu kakve varijetetske ili kabaretske družine koji nisu novinski oglašavali svoj dolazak i kratak ostanak u Puli (dovoljni su bili plakati). Putujući kinematografi tih su godina (do Prvoga svjetskog rata) u Pulu redovito stizali iz Trsta (rjeđe

19 „Georg Hengl, iz Beča (Fürstenfeld, 1856.), vlasnik (?) projekcijskoga aparata Chronophotograph koji su 1896. iznajmili Moritz Schuch i Nikolas Lauer iz Graza, kako bi prikazivali filmove, najprije u Grazu 1896., a zatim u Trstu, Rijeci, Puli i Ljubljani 1897. Hengl je svakako radio kao kinooperater, dok je organizator gostovanja bio Ferdinand Uršej. Poslije 1897. nema podataka o aktivnosti ove skupine u jugoslavenskim zemljama." Kosanović, Lekisikon pionira filma, 89.

20 „Chronophotographe“, Il giovine pensiero, 20. veljače 1897.

21 Naslovi tih pionirskih filmskih pokušaja bili su: Monumentalni vodoskok u Versaillesu, Trg pred Operom u Beču, Ženski dvoboj, Anšanski crnci se kupaju, Ulazak ruskoga cara u Pariz, Seljak, Postaja Saint-Lazare u Parizu, Krotiteljica zmija, Normandija, U zoološkom vrtu, Sat jahanja, Morska obala, Rad motora, Slonovi, Miss Loi Foller u serpentinskom plesu... Dejan Kosanović, „Prvi koraci filma u Rijeci: 1896-1918“, u: Ervin Dubrović (ur.), Kinematografija u Rijeci, Rijeka 1997., 24-25.

22 Kosanović, Trieste al cinema, 32; Srđan Knežević, „Prva kinematografska prikazivanja u Ljubljani (18961900)“, Zgodovinski časopis, 40, 3, 1986., 284.

23 Kosanović, Kinematografske delatnosti u Puli, 112-113. 
iz Ljubljane ili Rijeke, u koje bi dolazili opet iz Trsta), glavne austrijske trgovačke luke i središnjega grada Austrijskoga primorja (Österreichische Küstenland), jednoga od najvećih europskih obalnih gradova s više od 178 tisuća stanovnika na prijelazu stoljeća (usporedbe radi, Zagreb 1900. ima 57 tisuća, Pula 37, a Rijeka 30 tisuća stanovnika), kroz koji je prošlo 67 putujućih kinematografa ${ }^{24}$ i u kojem je do 1914. bila otvorena 31 kinodvorana $^{25}$, odakle profesionalni vlasnici kinematografa s putujućom kinoprikazivačkom opremom putuju i projiciraju filmove diljem Monarhije.

Prema dosad poznatim i raspoloživim arhivskim podacima te novinskim izvješćima, samo su četiri grada u današnjoj Hrvatskoj imala prve filmske projekcije 1896., a tri su projicirala „gibljive slike“ prije Pule: Zagreb (8. listopada), Karlovac (22. listopada) i Varaždin (4. studenoga). ${ }^{26}$ U AustroUgarskoj Monarhiji putujuća kinematografska mreža bila je razvijena i svi su veći gradovi već 1896. ili početkom 1897. imali privilegij upriličiti masovnu zabavu sve popularnijih živućih fotografija pa tako i po današnjim hrvatskim krajevima. „Tijekom 1897. godine projekcije živih slika održavane su po mnogim gradovima Hrvatske, posebno po primorskim i dalmatinskim gradovima, a od sljedeće 1898. godine može se uočiti sve življa djelatnost raznih putujućih kinematografa u Hrvatskoj.“27

Kinematografska zabava postaje uobičajena pojava, puljska svakodnevnica svih socijalnih i klasnih slojeva, poput posjeta sve brojnijim socijalno raslojenim kavanama i oštarijama ili navikavanja na novouspostavljeni redovni gradski prijevoz (1904.) električnim tramvajem. Kinematografi, osim što su bili pučka zabavišta, bili su i djelatnost koja je vlasnicima kinematografa donosila solidne zarade, komercijalno isplativ posao (ili dopunsko zanimanje) svakojakih poduzetnika, trgovaca, obrtnika i mešetara. „Nijeme, crno-bijele, titrave, žive slike mamile su publiku svake dobi i uzrasta, i to onu koja ne posjeduje svečana odijela i koja se ne vozi u kočiji (u ono vrijeme... u vrijeme još nerazvijenog filma!). Ta je činjenica bila dovoljna da zainteresira, kako posjednike malih kapitala (u slijedećem razdoblju bit će to posjednici velikih kapitala), tako i posjednike razigrane mašte, da se zajednički udruže u proizvodnju baš takvih živih

24 Isti, Trieste al cinema, 255-258.

25 Isto, 259-263.

26 Enes Midžić, Živuće fotografije i pokretne slike: razvoj kinematografske tehnike (dalje: Živuće fotografije i pokretne slike), Zagreb 2009., 300-301.

27 Dejan Kosanović, Počeci kinematografije na tlu Jugoslavije 1896-1918, Beograd 1985., 131. 
slika.“" ${ }^{\text {(28 }}$ Pokretljive sličice demokratizirale su zabavu (nema elitnih putujućih kinematografa), širom su otvorile vrata masovnoj kulturi i omogućile pristojnu, veliku i golemu zaradu djelatnicima u kinematografskom obrtu, budućoj filmskoj industriji. Kinematografska djelatnost krajem prvoga i početkom drugoga desetljeća 20. stoljeća već prelazi u filmsku industriju, u konkurentsko nadmetanje u profitu, kada dolazi do „trojne podjele kinematografske djelatnosti - na proizvodnju (stvaranje filma), distribuciju (promet) i prikazivalaštvo - koja se s određenim razvojnim mijenama održala sve do najnovijega doba.“29

\section{(Polu)stalno kino: slučaj kina Edison (1906.)}

Sveopća i nenadana popularnost filma tražila je svoj topli dom, namjensku zgradu ili dvoranu za svakodnevno projiciranje filmova. „Taj pokret, koji je počeo u Engleskoj, uskoro je neodoljivom snagom zahvatio Sjedinjene Američke Države, Francusku i cijelu Evropu."30 Prve kinodvorane (nakon improviziranih i povremenih) uvedene u SAD-u 1905. nazvane su niklodeonima (nickelodeons; prema nickel, kovanica od pet centi i odeon, antička zgrada za predstave, grč. odeion) i bile su ugodne, dobro vođene i organizirane. ${ }^{31}$ U Pittsburghu, rudarskom gradu u Pennsylvaniji, otvorena je 19. lipnja 1905. prva namjenska sala isključivo za projiciranje filmova, a iduće godine „otvoreno je 100 nikelodeona, a već 1908. bilo ih je između osam i deset tisuća u čitavoj Americi.“" ${ }^{\text {“2 }}$ U Europi je stalnih kinematografa tih godina mnogo manje (Europljane raduju i drugačije zabave), a uglavnom se, isključivo u namjenskom, kinoprikazivačkom obliku, u glavnim i većim gradovima $^{33}$ pojavljuju sredinom i krajem 1905. te početkom 1906. (potom se šire posvuda), premda su postojale slične kinematografske dvorane, kaza-

28 Belan, Sjaj i bijeda filma, 36.

29 Ante Peterlić, „Povijest filma“, u: Ante Peterlić (gl. ur.), Filmska enciklopedija, sv. 2 (L-Ž), Zagreb 1990., 358.

30 Georges Sadoul, Povijest filmske umjetnosti, Zagreb 1962., 67-68.

31 „Nickelodeoni skupljali su publiku iz najsiromašnijih društvenih slojeva, ponajviše iz redova doseljenika, a broj tih doseljenika prelazio je tada milijun ljudi na godinu. To mnoštvo ljudi koji su pretežnim dijelom dolazili iz Srednje Evrope nije moglo u kazalište, jer nije znalo engleski.“ Isto, 68.

32 Peter Bachlin, Ekonomska historija kinematografije, Zagreb 1951., 18, bilj. 1.

33 „Prva su stalna kinematografska kazališta nastala u velikim gradovima, i to još u vrijeme dok je obilazna kinematografija bila u punom cvatu, a razlikovala su se od ovih posljednjih jedino svojom većom stalnošću. Što je neko mjesto radije prihvaćalo obilazni kino, to je ono prije dobilo stalni kinematograf, koji se, istina, u samom početku smještao u kakvoj krčmi, kavani ili prodavaonici piva. Ova izmjena načina eksploatacije iz osnova je izmijenila i odnose između proizvođača i poduzetnika. Potražnja se filmova povećala, broj je kinematografskih kazališta porastao veoma brzo i programi su se zbog prilično ograničenog broja potrošača morali često mijenjati. Kao i obilazni kinematografi i ovi su novi poduzetnici kupovali filmove izravno od poduzetnika, i to na metre." Isto, 16-17. 
lišta, varijetei, kabarei, glazbena zabavišta, plesnjaci, kavanske prostorije i preuređene sale i prije 1905., u kojima su uzastopce ili dugo vremena (mjesecima, godinama) gostovali putujući kinematografi.

Prijelaz od putujućih preko polustalnih na stalne gradske kinematografe najčešće nije moguće sa sigurnošću utvrditi, napose pak pronaći granicu između ondašnjih polustalnih i stalnih kinematografa, kada se putujući kinematografi, nailazeći na dobar prijem, u pojedinim gradovima zadržavaju po nekoliko mjeseci (u za to unajmljenim gradskim prostorima), pokatkad i više od godinu dana (što u Puli nije bio slučaj) ili pak trajno, postajući tako polustalnim ili stalnim gradskim kinima koja neprestano mijenjaju filmski program pred stalnim gledateljstvom (dok su ranije mijenjali gledateljstvo sa stalnim programom, kolekcijom filmova). „Ponekad je teško razlučiti kada takav polustalni kinematograf preraste u stalni. Stalni kinematografi bili su otvarani kao posebna poduzeća s namjerom baviti se isključivo (ili prvenstveno) prikazivanjem filmova. $U$ tu svrhu su ili adaptirane neke postojeće prostorije ili su namjenski građene zgrade za kino od čvrstog materijala.“34

U Puli s poprilično aktivnim znanim i neznanim putujućim kinematografima (i vrlim Puljanima s kinoprojekcijskom opremom) u unajmljenim gradskim prostorima takve dvojbe i sumnje postoje (i još uvijek nisu primjereno riješene), napose s putujućim kinom Edison, zasigurno polustalnim ili možda već (prvim puljskim) stalnim kinematografom, i kinom Internazionale (u improviziranom paviljonu), koji je proglašen prvim stalnim puljskim kinematografom, te nešto manje s putujućim i kvalitetnim Théâtre Pathé Frères iz Pariza (Pathé Frères bio je „međunarodni filmski imperij“, samo u Americi distribuirao je i snimao više filmova od svih američkih kompanija zajedno), koji se u godinu dana, od 4. rujna 1907. do 30. rujna 1908., s poprilično dobrim programom ${ }^{35}$ pojavljivao četiri puta u Politeami Ciscutti, u ne

34 Dejan Kosanović, „Putujući, polustalni i stalni kinematografi na tlu Bosne i Hercegovine 1897-1941“, Sineast, 110, 1999., 77.

35 Repertoar Pathé Frèresa bio je za ono vrijeme raznolik, šarolik i sadržajan, primjera radi evo novinske najave projekcija: „Politeama Ciscutti, večeras na 8.30 održat će se sliedeći razpored: 1) Glazba; 2) Umjetni tokar, iz naravi; 3) Daska, šala; 4) Dvoboj hromastih, šala; 5) Gusari, drama 6) Zaručena pripoviest, šala; 7) Gospodja u Japanu, iz naravi; 8) Provalnik u zrakoplovu, šala; 9) Začarano tïjesto, priča; 10) Dosjetljivi zaštitnik, šala 11) U Sevilli, naravno; 12) Naša fanfara konkurira, šala; 13) Mulatova osveta, drama; 14) Dresirani psi, slike; 15) Lopov nad lopovima, šala 16) Ljubomornost medju sestrami, šala; 17) Djavolske fantasie, u boji; 18) Kratkovidni lovac, šala. Ulazne ciene: Ulaznina k prizemlju 60 p., Galerija 30 p., Stanica 2 K., Sjedalice 60 p., Sjedala u prizemlju 30 p., Posebna mjesta na galeriji sa ulazninom 50 p.“; „Théâtre Pathé Frères“, Omnibus, 21. rujna 1907 . 
pretjerano dugim terminima (ukupno oko četiri mjeseca: od 4. do 30. rujna ${ }^{36}$ i od 13. do 23. prosinca $1907 .{ }^{37}$ te od 27. svibnja do 2. kolovoza ${ }^{38}$ i nedugo poslije od 29. kolovoza do 30. rujna $1908 .^{39}$ ), ali nije se uspio stalno, na dulje vrijeme, nastaniti u kazalištu i zadobiti epitet stalnoga kinematografa, tek natruhe polustalnog.

Sala Edison (kako se najčešće novinski oglašavalo i reklamiralo kino) ili kinematograf Edison, na Portarati, otvoren je 25. travnja 1906. velikim najavama u Polaer Morgenblattu i u Il Giornalettu di Pola, ${ }^{40}$ za koji „zahvaljujući jednom pismu Carsko-kraljevskoga Policijskog komesarijata iz Pule od 21. travnja 1906. možemo sa sigurnošću tvrditi da je vlasnik Angelo Curiel iz Trsta, što znači da je riječ o putujućem kinematografu Edison i da ga treba razlikovati od stalnog kinematografa Edison koji je otvoren u Puli listopada iste godine. ${ }^{{ }^{41} 1}$ Kako su tada na trgu Slavoluka Sergijevaca bile dvije kavane, Nazionale i Commercio ${ }^{4 \cdot 2}$, valja s velikom sigurnošću pretpostaviti da je vlasnik, sada već ozbiljan i iskusan kinoprikazivač Angelo Curiel ${ }^{43}$ (u svakom slučaju bolji nego prije deset godina kada je, 21. studenoga 1896., zajedno s kompanjonom Maxom Karreiterom prevario Puljane) unajmio od vlasnika zgrade kavane Commercio, Karla Matelića (Matelich), njemu suvišnu kavansku salu koju je obnovio, namjestio i preuredio u kinodvoranu.

36 „Théâtre Pathé Frères, Politeama Ciscutti: Prima rappresentazione“; „Théâtre Pathé Frères, Politeama Ciscutti: Ultima rappresentazione“, Il Giornaletto di Pola, 4. i 30. rujna 1907.

37 „Teatro Pathé Frères, cinematografo di Parigi, Politeama Ciscutti: Nuovo!, Nuovo!“; , Teatro Pathé Frères, cinematografo di Parigi, Politeama Ciscutti: Ultima rappresentazione definitiva“, isto, 13. i 23. prosinca 1907.

38 „Politeama Ciscutti: Oggi mercoledì rappresentazione d'apertura Teatro Pathé Frères - Parigi“; „Politeama Ciscutti: Questa sera alle ore 9 ultima rappresentazione di Teatro Pathé Frères“, isto, 27. svibnja i 2. kolovoza 1908.

39 „Politeama Ciscutti, Teatro Pathé Frères di Parigi: Prima rappresentazione“; „Politeama Ciscutti: Teatro Pathé Frères di Parigi: Ultima rappresentazione“, isto, 28. kolovoza i 30. rujna 1908.

40 „Kinematograf 'Sala Edison', Piazza Port'Aurea, Ecke Via Giulia heute den 25. April (bis ink1. 30. April), Eröffnungs-Vorstellung...“, Polaer Morgenblatt, 25. travnja 1906.; „Cinematografo Sala Edison, Piazza Portaurea, angolo via Giulia, oggi: Grande apertura“, Il Giornaletto di Pola, 25. travnja 1906.

41 Kosanović, Kinematografske delatnosti u Puli, 37.

42 Bruno Dobrić, „Stare pulske kavane“, Hrvatska revija, 4, 2003., 43.

43 „Angelo Curiel bio je izdanak poznate porodice tršćanskih židova koja je ovom gradu dala u XIX. stoljeću više uglednih novinara. Angelo Curiel (godine rođenja i smrti su zasad nepoznate) bio je, također, novinar i kazališni impresario. Od 1882. do 1911., u raznim razdobljima, bio je vlasnik i urednik šest raznih časopisa, od kojih je najznačajniji Il corso di Trieste, kazališni satirično-humoristički tjednik s karikaturama koji je Curiel izdavao od 1899. do 1911. godine. On se godine 1896. zainteresirao, kao impresario, i za novi pronalazak koji je izazvao pozornost javnosti - kinematograf, a koji je prethodno već u dva navrata s velikim uspjehom prikazan u Trstu (srpnja i kolovoza). Ne napuštajući ostale svoje djelatnosti (novinarstvo, organiziranje kazališnih predstava), Curiel se od 1896. godine pa sve do kraja Prvoga svjetskoga rata, bavio i prikazivanjem filmova, isprva kao putujući prikazivač, a nešto kasnije i kao vlasnik stalnoga kinematografa. (...) Godine 1906. Angelo Curiel javlja se kao vlasnik (ili impresario?) putujućeg kinematografa Edison..."Kosanović, „, Ko je bio Angelo Curiel?“, 74-75 i 77. 
Zanimljive su prednajave, mjesec dana prije otvaranja, o Sali Edison, oglas u Giornalettu ${ }^{44}$ i vijest u Omnibusu ${ }^{45}$, koje izravno upućuju kako je riječ o stalnom puljskom kinematografu: „Jedan trgovac kani u Puli, kao u drugim velikim gradovima, namjestiti jedan kinematograf sa dnevnim predstavama. Isti namjerava pružiti gradjanstvu i drugih zabava. ${ }^{46}$ Prema najavi, Curiel je imao ozbiljne namjere s preuređenjem sale u kinodvoranu u kojoj bi njegov putujući kinematograf prestao putovati i pretvorio se u stalno kino u Puli, a čim je „namjeravao pružiti gradjanstvu i drugih zabava“, htio je poslovanje proširiti i trajnije ostati u Puli. Drugi dan nakon otvorenja Sale Edison, u kratkoj se Omnibusovoj vijesti ponovno pojavljuje i izrijekom spominje pojam „stalni kinematograf“: „Jučer je bilo otvorenje dvorane kinematografa na uglu Ulice Giulia i Portarate. Ovaj kinematograf je stalan u Puli te će davati predstave svaki dan.“77 I tjedan dana nakon otvorenja kinematografa Edison u kratkom komentaru na talijanskome jeziku ponovno ista fraza, il cinematografo permanente (stalni kinematograf): „Na uglu Trga Port'Aurea i Ulice Giulia prije nekoliko dana otvoren je stalni kinematograf. Plodonosan posao i predstave koje posjećuju brojni građani i zadržavaju se na trgu učinili su taj trg puno življim. Uvjereni smo da gradu Puli upravo takve predstave mogu dati onu trajnu vitalnost koja mu nedostaje." ${ }^{\text {"8 }}$

Curielov je putujući kinematograf imao (kako puljske novine objavljuju) dobru posjećenost i bio vrlo popularan u gradu: „Kinematograf na uglu Ulice Giulia i Port’Auree gledatelji masovno hitaju posjetiti. Jučer je prikazano 15 predstava. ${ }^{49}$, „Sve jučerašnje predstave u kinu kod Zlatnih

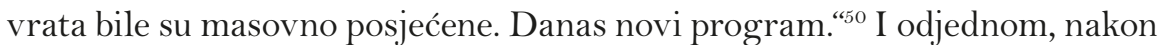
samo 37 dana prebivanja u kinodvorani, kinematograf Edison ili Sala Edison (Polaer Morgenblatt i Il Giornaletto di Pola objelodanili su u tom razdoblju 12 napisa o kinematografu Edison i 27 oglasa s programima), već 31.

44 „Preavviso. Portaurea, angolo via Giulia, prossima apertura del Cinematografo permanente 'Edison'. Senza oscillazioni“, Il Giornaletto di Pola, 18. travnja 1906.

45 Omnibus je Laginjin puljski trojezični dnevnik (izlazio je kao dnevnik samo od 15. listopada 1904. do 30. lipnja 1906., kada postaje tjednik do 29. svibnja 1909., kasnije do lipnja 1914. izlazi vrlo iznimno i jako povremeno, samo pred izbore), ponajviše na hrvatskome, nešto manje na talijanskome i ponajmanje na njemačkome jeziku, koji Dejanu Kosanoviću, prema popisu novinskih dnevnika i tjednika, nije bio dostupan. Kosanović, Kinematografske delatnosti u Puli, 116.

46 „Stalni kinematograf“, Omnibus, 20. ožujka 1906.

47 „Stalni kinematograf u Puli“, isto, 26. travnja 1906.

48 „Il cinematografo permanente“, isto, 2. svibnja 1906.

49 „Cinematografo Edison“, Il Giornaletto di Pola, 30. travnja 1906.

50 „Cinematografo Edison“, isto, 21. svibnja 1906. 
svibnja 1906. napušta grad u nepoznatom smjeru, gubi mu se svaki daljnji pouzdani trag. „Naime, mjeseca kolovoza iste 1906. gostovao je i u Sarajevu kinematograf Edison. Ime vlasnika ili impresarija ovoga kinematografa zasada ne znamo, ali je sasvim moguće da je to bio Angelo Curiel. (...) Podataka o gostovanju kinematografa Edison po nekim gradovima Dalmacije između kraja svibnja i kolovoza 1906. ima, ali se ime Angela Curiela nigdje izričito ne spominje (kao ni u Sarajevu). ${ }^{“ 51}$ Zašto je Angelo Curiel, nakon što je uložio (najvjerojatnije) svoj novac u prenamjenu kavanske sale u kinodvoranu uz pompoznu najavu stalnoga kinematografa u Puli, naglo otputovao iz Pule usred masovne posjećenosti i gradske popularnosti, nije poznato: ostaju samo spekulacije bez vjerodostojnih povijesnih podataka (možda zbog velike novinske najave i konkurencije novoga kinematografa Internazionale u Puli, veće zarade u Sarajevu i po Dalmaciji, zanosne Dalmatinke ili nove ljubavi u Sarajevu...).

Iz navedenoga nije jasna pozicija i kategorija kinematografa Edison u Puli, tim prije što je bio stacioniran u prilagođenom, obnovljenom, namještenom, primjerenom i solidnom prostoru zgrade (daleko solidnijem od uskoro podignute montažne barake, paviljona, za prvi povijesno priznati stalni kinematograf Internazionale u Puli), ondašnje inačice kinodvorane, usred grada, te je imao sve odlike stalnoga kinematografa (svakodnevne projekcije s izmjenom programa u isključivo ili pretežito za to namijenjenoj dvorani), iako u funkciji putujućega kinematografa. Njegova relativno kratka postojanost (37 dana) ide u prilog putujućega kinematografa, a gotovo sve ostalo u prilog stalnoga kinematografa, poglavito činjenica da je nedugo potom u istom prostoru bio Covinijev putujući kinematograf koji će uskoro postati stalan - dakle, u tom istom prilagođenom prostoru otvoreno je drugo (službeno) stalno kino u Puli (nakon kina Internazionale), kinematograf Excelsior. Postoji očit kontinuitet kinoprostora na trgu Portarata, $\mathrm{u}$ kojemu stoluju stalni kinematografi (različitih vlasnika i imena) na istome mjestu (u istoj zgradi) u Austro-Ugarskoj i kasnije (u doba Italije), prostoru koji je inaugurirao Curielov kinematograf Edison.

Neodređenost i fluidnost pojmova putujući (je li putujući ako se dugo zadržava na istome mjestu?), polustalni (neodredivo rastezljiv pojam između putujućih i stalnih) i stalni kinematograf (koliko je vremena kontinuiranoga projiciranja i što je sve potrebno da se neki polustalni kinematograf proglasi 
stalnim u čvrstom objektu?), ostavlja široku mogućnost određivanja kinematografa Edison - može ga se okvalificirati i putujućim i polustalnim i stalnim. Dok se god metodički i terminološki točno ne odrede te kategorije (i definiraju pojmovi) neće se znati ni prava kategorija Curielova kinematografa Edison u Puli. Zasad, prema današnjim spoznajama rane kinematografije (filmske arheologije) i dostupnim povijesnim podacima, zasigurno spada u polustalne (ako već ne u stalne) kinematografe. Prepustimo budućim povjesničarima i istraživačima rane kinematografije u Hrvatskoj razrješenje problema, uz uzgrednu napomenu: ako je Sala Edison na Portarati bila zaista stalni kinematograf, tada i prvi puljski kinematograf Edison spada $u$ prve malobrojne stalne kinematografe do konca 1906. u Hrvatskoj (ukupno svega pet kina - tri puljska: Internazionale, Excelsior i drugi Edison, jedan riječki: Salone Edison i jedan zagrebački: Union) jer je samo 12 dana poslije istoimenoga riječkoga kinematografa (Salone Edison, 13. travnja 1906. ${ }^{52}$ počeo s projiciranjem filmova.

Malo potom kinofikacija grada nastavlja svoju ubrzanu puljsku misiju (poput ostalih tjelesnih, alkoholnih, kabaretskih, kulturnih i duhovnih zabavišta), niču stalni kinematografi umalo iz mjeseca u mjesec. Jedino je Pula na današnjem teritoriju Hrvatske imala te 1906. godine više od jednoga stalnoga kina (sve zajedno četiri, ubrajajući i prvi Edison), a Rijeka i Zagreb po jedno. „Ali nema zavaravanja: kada izdaleka vidite električnu svjetiljku koja probija gusti mrak ulice, kad čujete škripući glas fonografa što vam neugodno ranjava bubnjiće, ili onaj ne manje neugodan glas dječaka (vratara) koji hvali veličanstvenost predstave i umiruje nestrpljenje drugih s jednim veoma lažljivim: 'Počinje odmah!', onda možete biti sigurni da je tu kinematograf." ${ }^{“ 53}$

\section{Kino Internazionale (1906.) - drugo kino u Hrvatskoj}

Vlasnik prodavaonice mješovite robe (drogerije) u Ulici Sergijevaca (najprije u Via Sergia $53^{54}$, potom $49^{55}$ ), trgovac Ivan Tominc ili Giovanni Tominz ${ }^{56}$,

52 Nana Palinić, „O povijesti riječkih kinematografa - prvi stalni kinematografi: Salone Edison, Elektra, Progresso“, Dometi, 7-12, 1997., 97-110.

53 „I cinematografi“, Il Dalmata, 28. prosinca 1907., u: Duško Kečkemet, Počeci kinematografije i filma u Dalmaciji (1897-1918), Split 1969., 110

54 „Usate la Cimincina“, Il Giornaletto di Pola, 21. lipnja 1902.

55 „Comunicato“, isto, 22. listopada 1902.

56 „Ivan Tominc, drogerist iz Pule (Trst, 1877.). Godine 1905. nabavio je kinoprojektor i prikazivao filmove u Puli (i drugim gradovima Istre). Lipnja 1906. otvorio je prvi stalni kinematograf Internazionale.“ Kosanović, Leksikon pionira filma, 222. 
slovenski Tršćanin koji se sredinom 1902. doselio u Pulu ${ }^{57}$ šireći svoju djelatnost (i potencijalnu zaradu) na živuće sličice (dozvolu za kinematografsku prikazivačku djelatnost dobio je od Carsko-kraljevskoga namjesništva za Primorje još 4. svibnja 1905., ali ju je podigao tek 22. listopada) ${ }^{58}$, dao je podignuti dvoranu, provizornu baraccu, s jedinom namjenom projiciranja filmskih programa. U današnjem središtu grada, trbuhu Pule, pokraj nedavno izgrađene secesijske Glavne tržnice (1903.), ondašnjega građevinskoga čuda moderne željezne konstrukcije i stakla, niklo je posebno improvizirano (montažno) zdanje (negdje na početku današnje Fontičke ulice, prodavaonice Brionke, ili u neposrednoj blizini), paviljon za projiciranje filmova.

Prvi službeno proglašen stalni puljski kinematograf (naveliko najavljivan 22. svibnja ${ }^{59}$ i svakodnevno reklamiran 30. i 31. svibnja te 1. lipnja ${ }^{60}$ ), Električno kino Internazionale, Bioscopio elettrico Internazionale, svečano je otvoreno i počelo s redovitim prikazivanjem filmova 3. lipnja 1906. „Danas u 6 sati navečer otvaranje veličanstvenoga Elektro-kina Internazionale, u bezimenoj uličici nadomak Tržnice, na Verdijevom trgu, kazalište sa senzacionalnim prikazivanjem savršenih živih slika (...). Tri velike predstave dnevno: radnim danom u 7, 8 i 9 sati navečer, nedjeljom i praznikom od 6 sati navečer." ${ }^{\text {"61 }}$ Sutradan ga je Il Giornaletto već prozvao, prema vlasniku, kino Tominz (cinematografo Tominz): „Sinoć je otvoren novi kinematograf gospodina Tominza pored Priorina kioska. Posjet je bio mnogobrojan. Izvijestit ćemo vas još.“涝 „Posjetili smo paviljon koji je sagradio gospodin Tominz za električni kinematograf (ulaz kod kioska Priora). ${ }^{63}$ Moramo naglasiti, paviljon je vrlo lijepo uređen, a dobro projiciranim slikama brojni gledatelji plješću, što filmovi i zaslužuju. Za vrijeme i u stankama prikaziva-

57 Kosanović, Trieste al cinema, 81. Kosanović pogrešno imenuje Tominza talijanskom inačicom Giuseppe (Jožef Tominc ili Giuseppe Tominz, 1790. - 1866., slovensko-talijanski je slikar, bidermajerski portretist), a ne Giovanni (1877. - ?), kako u više navrata reklamira svoju drogeriju u Via Sergia 49 u Il Giornalettu di Pola, što pak ne isključuje neku rodbinsku povezanost.

58 Kosanović, Kinematografske delatnosti u Puli, 31.

59 „Preavviso: Prossimamente grande apertura del meraviglioso Bioscopio elettrico Internazionale (sistema Engelsmann) vicino al Mercato di Piazza Verdi, Chioschi Priora. Devotissimo proprietario G. Tominz“, Il Giornaletto di Pola, 22. svibnja 1906.

60 „Voranzeige“, Polaer Morgenblatt, 30. i 31. svibnja te 1. lipnja 1906.

61 „Eröffnung der großartigen internationalen Elektro-Bioskops“, isto, 3. lipnja 1906.

62 „Cinematografo Tominz“, Il Giornaletto di Pola, 4. lipnja 1906.

63 Kiosk ili kiosci Priora bili su prodavaonice tekstilne i konfekcijske robe pristupačnih cijena: „Amerikanskoj trgovačkoj kući (pokraj tržišta, kioski Priora) stigao je bogati izbor robe zadnje mode za ljetnu sezonu, uz ciene za čudo nizke. Pregledavanje slobodno, ulaz besplatan!“, „Brzojav!“ (reklama), Omnibus, 30. svibnja 1906. 
nja sviraju glazbenici gradskoga orkestra." ${ }^{64}$ Samo tri dana nakon odlaska Curielova kinematografa Edison Puležani nastavljaju s odlascima u kino, više ne idu na Portaratu već na obližnji trg Gradske tržnice, u kino Internazionale (cinema ili cine Internazionale) ili, prema vlasniku, kino Tominc (cinema ili cine Tominz), kako su ga kratko nazivali, dakle nikada u kino Internacional, kao što se uporno i stalno pogrešno navodilo i navodi (kao i engleski International). ${ }^{65}$

Tomincu, običnom poduzetniku i još običnijemu drogerijskom trgovcu, priprostom prodavaču i neobrazovnom vlasniku drogerije, nije bilo nimalo stalo do filmske kulture, kinematografije ni do stalnoga kina u Puli. Cinema je Internazionale Tomincu bila samo još jedna prodavaonica (da umjesto drogerijske prodaje filmsku robu), izvor prihoda i apsolutno ništa više od toga. Premda je u početku kino dobro prihvaćeno ${ }^{66}$ (kako i ne bi kad je bilo jedino stalno kino nakon kinematografa Edison), kasnije se, kad je ipak trebalo poznavati i pratiti kinematografsku produkciju, Tominc pokazao popriličnom neznalicom i nevještim kinoprikazivačem. Shvativši da se preračunao, da mu kino nikako nije dovoljno profitabilno, već negdje oko 15 . srpnja ${ }^{67}$ pre-

64 „Cinematografo Tominz“, Il Giornaletto di Pola, 5. lipnja 1906.

65 Dejan Kosanović u Kinematografskim delatnostima u Puli ne zapisuje izvorno ime kina već samo srpsku (fonetsku) inačicu za cinema Internazionale - kinematograf (ili bioskop) Internacional, koji se još ranije pojavljuje i u napisu Marijana Grakalića, „Pula: od 'Internacionala' do Festivala jugoslavenskog filma“, Filmska kultura, 46-47, 1965., 179-183, a Albin Čehić pak u „Nino Giorgesi: filmski kroničar Pule“, Filmska kultura, 72, 1970., 77-79, potpuno pogrešno citira i interpretira varljiva sjećanja Nina Giorgesija i zapisuje ga kao „Bioscop International“. Naravno, i u Istarskoj enciklopediji pod leksikografskom jedinicom „kinematografija“ (387), u kojoj je autorski dvojac Mate Ćurić i Giuseppe Orbanich (ili Josip Orbanić, kako se još od zgode do zgode potpisuje, nije se dosjetio da Puležani, i Talijani i Hrvati i Nijemci, ne bi baš tako ni nazivali, a još manje tako zapisivali ime kina), ne provjeravajući izvore (ne pada im na pamet), doslovce prepisao Kosanovićevu srpsku varijantu, piše netočno kino Internacional.

66 Na ne baš veliku sreću (zapravo, na veliku nesreću) postoji nepotreban kronološki zapis svjedoka, mladoga sudionika kinematografskih početaka u Puli, kinoizvikača, imbonitorea Nina Giorgesija, dugo vremena jedinoga izvora (gotovo uvijek pogrešnih) podataka početaka kinoprikazivačke djelatnosti u Puli. „Njegova kronika započinje 23. lipnja 1906. godine, kada je u Puli otvorena prva stalna kinematografska dvorana. Bio je to 'Bioscop International', smješten pod jednim prilično stabilnim šatorom pod koji je moglo stati stotinjak gledalaca. Šator se nalazio u tadašnjoj ulici Innominita, između sadašnje gradske tržnice i Muzičke škole. Nino Giorgesi je tada i dobio svoje stalno namještenje koje se sastojalo u tome da dijeli plakate sa sadržajem filmova i uopće da privuče publiku u kino. To se radno mjesto zvalo imbonitore. Prvi film koji je prikazan zvao se 'Kralj od Španije’. Bila je to spektakularna i za ono vrijeme neviđena filmska gala-predstava, a s druge strane - otvorenje prvog kina predstavljalo je značajan kulturni i društveni događaj.“ Čehić, „Nino Giorgesi: filmski kroničar Pule“, 77-78. Ne možemo se i ne smijemo pouzdati u Giorgesijeva sjećanja (još manje vjerovati novinaru koji tako olako objavljuje i podastire toliko neprovjerenih podataka), počevši od pogrešno zabilježenog imena prvoga stalnog kina, pogrešnoga datuma otvorenja te šatora kina Internazionale (stalno kino u šatoru?!), koji prema „programu slika“ iz Polaer Tagblatta i Il Giornaletta di Pola 23. lipnja 1906., nema ni traga spektaklu Kralj od Španije (po svemu sudeći, vjerojatno je riječ o kasnijem filmu Vjenčanje španjolskog kralja $i$ atentat, na programu 15. srpnja 1906., netom ufilmljenim stvarnim događajem u 8 slika, 31. svibnja 1906., kada je kraljevski par, Alfons XIII. i Viktorija Eugenija, po povratku s vjenčanja, zamalo izbjegao pogubni ishod atentata katalonskoga anarhista Mateua Morrala Roce, čija je bomba u buketu cvijeća bačena na kraljevsku kočiju usmrtila 23 prolaznika i sudionika kraljevske povorke u Madridu).

67 „Bioscopio Elettrico Internazionale“, Il Giornaletto di Pola, 15. srpnja 1906. 
staje sa svakodnevnim filmskim projekcijama (nema kao ranije redovitoga objavljivanja filmskoga programa u dnevnim novinama) i pod izlikom ljetnoga raspusta i pasje vrućine prikazuje filmove samo nedjeljom ${ }^{68}$, a krajem kolovoza prestaje i s nedjeljnim projekcijama (posljednji oglas pojavljuje se 12. kolovoza, ${ }^{69}$ a najava 19 . kolovoza $^{70}$ ) te počinje s ugošćivanjem komedijskih putujućih kazališnih i lutkarskih družina, kabarea i varijetea (u novinama nakratko postaje neugledan teatarčić, teatrino) ${ }^{71}$. Slabo isplativa kinematografska djelatnost (i ozbiljna konkurencija novoga kina Excelsior) ubrzo mu je dojadila pa krajem rujna prodaje improviziranu baraku kina Internazionale i vraća se svojim poznatim trgovinskim poslovima i drogeriji. Ipak, zahvaljujući trgovcu Tomincu započeto prikazivanje gibljivih sličica, filmskih projekcija u bezimenoj uli(či)ci (via innominata, unbenannte Gasse) nadomak Tržnice nastavilo se i kasnije, pod novim imenom i s novim vlasnikom.

Usporedimo li Salu Edison s putujućim Curielovim kinematografom i kinematograf Internazionale, Edison je svakodnevno prikazivao filmove 37 dana (i noći) u pristojnoj kinodvorani, a Internazionale 44 dana u improviziranom paviljonu, provizornoj baraci. Nameće se pitanje prema čemu kinematograf Internazionale spada u stalna kina i samim time postaje prvo stalno kino (povijesno službeno, prema Kosanoviću) u Puli (u improviziranoj baraci), a Sala Edison tu kvalifikaciju nema (zbog putujućega kinematografa iz Trsta), kad je vrijeme svakodnevnoga projiciranja filmova približno jednako (razlika je 7 dana, uz daleko bolje prostorne uvjete u Sali Edison) i u oba su prostora i kasnije nastavljena kinematografska prikazivanja, otvaraju se nova kina. I Kosanović, vrsni poznavatelj rane kinematografije na jugoslavenskim prostorima, nije siguran, ostavlja tu nedoumicu otvorenom: „Mjeseca lipnja 1906. godine otvoren je u Puli prvi stalni kinematograf, koji je radio neprekidno manje od dva mjeseca, pa bismo ga mogli lakše podvesti pod naziv polustalni kinematograf. ${ }^{\text {“72 }}$ Realno i zdravorazumski proizlazi da su oba kinematografa, i Edison i Internazionale, polustalna kina (ili, prema umjerenijim i labavijim kriterijima, stalna kina), ali je Internazionale, zbog toga što nije bio putujući (otvorio ga je stanovnik Pule), postao stalni kine-

68 „Ovaj kinematograf u blizini kioska Priora već neko vrijeme, zbog pasje vrućine, nema predstava tijekom tjedna i otvoren je samo nedjeljama, uvijek s novim programom.“, „Cinematografo Tominz“, isto, 29. srpnja 1906 .

69 „Cinematografo Tominz: rappresentazioni soltanto alla domenica“, isto, 12. kolovoza 1906.

70 „I trattenimenti d'oggi“, isto, 19. kolovoza 1906.

71 „Le marionette“, isto, 8., 9. i 10. rujna 1906.

72 Kosanović, Kinematografske delatnosti u Puli, 38. 
matograf, unatoč samo 44 dana uzastopnih prikazivanja filmova u baraci, a putujući Edison u boljim uvjetima, koji je u Puli zastao 37 dana u kinodvorani, to nije.

\section{Kino Excelsior (1906. - 1908.) - treće kino u Hrvatskoj}

Drugi stalni kinematograf u Puli (a možda, prema blažim kriterijima, i treći) te treći u današnjoj Hrvatskoj, kino Excelsior (zvano i Salon Excelsior), smjestio se u kinematografski prilagođenoj dvorani kod Zlatnih vrata (na trgu današnjega i tadašnjega naziva Portarata), onoj istoj sali u kojoj je gostovao od 25. travnja do 31. svibnja (polu)stalni kinematograf Edison. Službenoga otvaranja kina nije bilo, niti je zabilježeno kada je (putujući) kinematograf stigao u Pulu. Prvi spomen kina Excelsior nalazimo u novinama, u ponedjeljak 16. srpnja 1906. (baš na izdisaju kina Internazionale), kad se spominje u kontekstu policijske intervencije: „U subotu navečer kino Excelsior na Portarati predstavilo je novi program na kojemu je, između ostalog, bio i kratki film (slika, quadri, kako su tada nazivali kratke filmove, op. a.) iz ruske revolucije. Već su bile projekcije četiriju predstava pred brojnom znatiželjnom publikom, kad su im prema nalogu Policijskoga komesarijata taj film zabranili projicirati, tako da se od jučer umjesto njega prikazuje film 'Detektiv', za koji također postoji interes gledatelja“73. Naravno, ova zabrana izazvala je proteste i polemike lijevih političkih stranaka i proleterskih društava koja su žestoko napala takvu policijsku zabranu i režimsku cenzuru (ne samo u Puli). Ne zalazeći u zanimljivu novinsku polemiku o slobodi filmskoga prikazivanja i cenzuri, ${ }^{74}$ nama je važno pojavljivanje novoga kina u Puli, koje je, prema svemu sudeći, kako nije bilo službenoga otvaranja, započelo kao putujući kinematograf u postojećoj kinodvorani na Portarati koji je tu ostao i postao stalnim puljskim kinematografom.

Kino se Excelsior na Portarati u Puli smjestilo (u svakom slučaju) prije datuma zabrane projiciranja filma iz ruske revolucije, dakle krajem lipnja ili početkom srpnja 1906. (možda i prije), no zasad ne znamo točno kada. ${ }^{75}$ Budući da nije najavljeno u novinama, riječ je sigurno o putujućem kinema-

73 „Cinematografo Excelsior“, Il Giornaletto di Pola, 16. srpnja 1906.

74 „Per viste di ordine pubblico“, isto, 17. srpnja 1906.; „Ebetismo o malafede“, isto, 22. srpnja 1906.

75 Kosanović zapisuje dva i pol mjeseca kasniji datum, 23. rujna 1906., kad je pronašao prvu vijest o kinu Excelsior (budući da mu je promakla ova policijska zabrana, ili nije imao kompletno godište Giornaletta, i još neka kasnija usputna spominjanja kina Excelsior koje, nedosljedno, ne zapisuje u srpskoj fonetskoj inačici Ekscelzior, već izvorno), ali uz napomenu: „izgleda da je kinematograf Excelsior kod Zlatnih vrata već izvjesno vrijeme održavao predstave (čim se spominje novi program)“. Kosanović, Kinematografske delatnosti u Puli, 41 . 
tografu koji je naišao na vrlo dobar prijem Puljana (kao tada jedino stalno kino, pored putujućih u Politeami i nakon ugasloga kina Internazionale) i tu ostao. Vlasnik kina bio je izvjesni gospodin Covini (nije, kako dvoji Dejan Kosanović, gospodin slična prezimena, Oreste Corvini, za kojega talijanski povjesničar filma Aldo Bernardini napominje da je bio iz Pule $)^{76}$, gospodinu se ne zna ime, ${ }^{77}$ ali poznato je ime njegove supruge (Teresa Covini) i njegova kinooperatora (Arnaldo Pozzo) koji se javno, u novinama, ispričao gospođi za izgovorene uvrede. ${ }^{78} \mathrm{U}$ svakom slučaju, Covini je dobro poznavao kinematografsku djelatnost i produkciju, pratio tehnološka dostignuća i Puljanima stalno nudio nove, svježe filmove, najnovije programe s najistaknutijim filmovima, kao recimo i najnovijim snimkama odlaska i dolaska parobroda Wurmbranda (onoga istoga kojim su zaljubljeni James Joyce i Nora Barnacle uplovili u Pulu 30. listopada 1904.) snimljenim iz Pule. ${ }^{79}$ Brinuo je Covini (pored recentnih programa) i o kinu na Portarati: „Prekrasan novi program prikazan je sinoć u ovome kinematografu. Posebno divljenje izazvali su filmovi 'Radžin kovčeg' (u boji) i ‘Oružja i ljubavi’. Za koji dan najavljeno je otvorenje posebne čekaonice za posjetitelje ovoga kina.“80 Dostojanstvena, široka i prostrana čekaonica za sve veći broj posjetitelja preuređenoga kina svečano je otvorena 6. listopada ${ }^{81}$ i od tada kinematograf Excelsior postaje omiljenim mjestom i za ugledniju gradsku gospodu (zamalo elitnim kinom). Puljska kinematografska publika pojavom kina više nije filmski jedinstvena, premda je i prije bila cijenom ulaznica razjedinjena (ali su svi gledatelji bili na istome mjestu); vraća se u stare poznate okvire (sada još jednoga) gradskoga raslojavanja - socijalne, klasne i kulturološke podjele gledanja filmova u skorašnjim kinodvoranama.

Prvo uistinu stalno puljsko kino Excelsior (nema prijepora ni nedoumica kao kod kinematografa Edison i Internazionale, osim što mu ne

\footnotetext{
76 Isto, 42.

77 „Covini, bliži podaci nepoznati. Vlasnik stalnog kinematografa Excelsior koji je 1906. otvoren u Puli i koji je kontinuirano radio do Prvoga svjetskog rata (uz promjenu naziva 1908. u kino Minerva). Covini je, vjerojatno, naručio 1907. snimanje filmova o Puli: 'Dolazak i odlazak broda Wurmbrand', 'Izlazak naroda iz Katedrale', 'Katedrala' i 'Tržnica' koji su prikazani u njegovom kinematografu." Isti, Leksikon pionira filma, 117 .

78 „Na glasine, koje već nekoliko dana kruže, o prijetnjama koje sam izgovorio gospođi Teresi Covini, želim izjaviti: ako sam se izrazio nepristojno i na nepriličan način, to je bilo zbog toga jer sam bio uzbuđ en i zato osuđujem svaku riječ koju sam izgovorio bez razloga. Pula, 19. ožujka 1907. Arnaldo Pozzo, operator u kinu (operatore al Cinematografo, op. a.).“ „Comunicato“, Il Giornaletto di Pola, 22. travnja 1907.

79 „I trattenimenti d'oggi“, isto, 19. kolovoza 1906.

80 „Cinematografo Excelsior“, isto, 23. rujna 1906.

81 „Al cinematografo di Portaurea“, isto, 7. listopada 1906.
} 
znamo datum, ako ga je uopće bilo, službena otvaranja), iako cijelo vrijeme (u dvije godine: 1907. i 1908.) recentna repertoara i filmskoga programa (mijenjanim svaka 3-4 dana) stalno najavljivanih u dnevnom tisku (dvjestotinjak vijesti uza svakodnevni program u oba puljska dnevnika) ${ }^{82}$ i, naravno, s najnovijim prilozima za „crne večeri“ samo za gospodu, ${ }^{83} \mathrm{~s}$ kvalitetnim suvremenim projektorima (kinoprojektori Pathé, „apsolutna novost za Pulu“) ${ }^{84}$ i projekcijama koje prati živa klavirska pratnja, a utorkom i mali sastav orkestra Carsko-kraljevske mornarice te s promocijama prvih onodobnih ozvučenih filmova od 25. travnja do 16. lipnja 1908. (sinkroni uređaj prikaza filma i glazbe s gramofonskih ploča, većinom puljskim malograđanima omiljenih operetnih i opernih arija ili popularnih skladbi, belcanta $)^{85}$, sredinom 1908. zapada u financijsku krizu. Vlasnik Covini prodaje kino izvjesnoj gospođi Benussi, a ona, pak, malo potom puljskom ugostitelju Karlu Mateliću (Matelichu) i 31. listopada 1908. Excelsior mijenja naziv u kino Minerva.

\section{Besramne mrkle noći}

Spomenute „crne večeri“ nisu se prvi put pojavile u kinu Excelsior. Osam godina prije, još 17. prosinca 1898., objavljena je puljska izazovna najava vlasnika putujućega kinematografa Johanna Bläsera, ${ }^{86}$ koji je u Carrarinoj ulici, u privremeno podignutom šatoru, ${ }^{87}$ smjestio improvizirano kino: „U 8 sati navečer predstava je rezervirana isključivo za muškarce, cijena ulaznice 30 novčića. “88 To je, koliko je poznato, službeno prva puljska javna (ne možemo

82 U Il Giornalettu di Pola kino je Excelsior imalo privilegij, nije objavljivao plaćene oglase već se program svaka 3-4 dana objavljivao u gradskoj rubrici „Notizario cittadino“.

83 „Večeras i sutra navečer u 8.30 i kasnije priređuju se 'crne večeri' samo za odrasle osobe.“, „Cinematografo Excelsior“, isto, 5. studenoga 1906

84 „Kinematograf Excelsior“, Polaer Tagblatt, 28. srpnja 1908.

85 „Kinematograf Excelsior“, isto, 10. svibnja 1908.

86 „Jochann (Johann, Jean, Giovanni, Ivan) Bläser (Herford, 1863.), putujući zabavljač i vlasnik kinematografa iz Wormsa u Njemačkoj. Bavio se prikazivanjem raznih atrakcija, a od 1896. vlasnik putujućeg kinematografa koji je pod raznim nazivima (Cinematografo, Cinematografo Edison, Edisonov kinematograf, Bioscop, Bioskop) prikazivao filmove u sjevernoj Italiji i Austrougarskoj Monarhiji - u Trstu, Mariboru, Celju, Ljubljani, Puli, Rijeci, Varaždinu, Zagrebu itd. Tom prilikom je u nekim gradovima u kojima je boravio snimao i prikazivao lokane filmove, često prve filmske kadrove u tim mjestima: Korzo u Rijeci, Panorama Ljubljane (1899.), Riječka luka, Porinuće Szigetvára u brodogradilištu Uljanik (u Puli, 1903.), Isplata mornara na brodu Radetzky (u Puli, 1903.) i druge; ni jedan od tih filmova nije sačuvan. Od 1910. vlasnik stalnog kinematografa u Linzu (Austrija) i do kraja života ugledni član Udruge vlasnika kinematografa Austrije." Kosanović, Leksikon pionira filma, 30-31.

87 „Bläser je imao putujući kinematograf sa vlastitim šatorom površine 96 kvadratnih metara, što znamo iz radne dozvole koju je dobio u Rovinju." Kosanović, Prvi koraci filma u Rijeci: 1896-1918., 29.

88 „Alle 8 di sera lo spettacolo è riservato esclusivamente agli uomini, ed al prezzo di ingresso di soldi 30.“, „Cinematografo“, Il popolo istriano, 17. prosinca 1898. 
nikako isključiti mogućnost pokojih tajnih) projekcija filmića razodjevenih ili već mogućih erotskih sadržaja, tada nimalo zagonetno okvalificiranih s „isključivo za muškarce“. „Poseban uspjeh su imale posebne predstave za gospodu ili takozvane crne predstave na kojima su prikazivani filmovi pikantnog sadržaja, u širokom rasponu od frivolne salonske erotike do nagovještaja prave pornografije. “99 Naravno, takve su mračne besramne projekcije (redovito skuplje, do dvostruko skuplje od redovitih) bile jako popularne i vlasnici su ih putujućih kinematografa, gdje su god gostovali, rado imali na programu, zavisno od grada, ili svaku večer ili jedanput-dvaput tjedno.

Vjerojatno je nešto kasnije, poslije Bläsera, početkom ili sredinom iduće godine, za što nema (i nema razloga biti) pouzdanih javnih podataka kada i gdje - ali zasigurno negdje u Puli, ako ništa drugo makar na zatvorenim, privatnim projekcijama (u dobrom društvu) - i mehaničar iz Pule, vlasnik projekcijske aparature zvane taumatograf (thaumatograph, još jedna od silnih projekcijskih naprava), Max Schüler ${ }^{90}$ (odnedavni stanovnik Pule, od 1895., za kojega u dosjeu stoji, kako je austrijski pedantno evidentirano, da je „sudski i policijski čist te da na njegovo ponašanje nema nikakvih primjedbi“91) projicirao (u mrklom mraku) za odabrano društvo lascivne, „razodjevene“ filmiće. Naime, Schüler je besramne filmove posjedovao, to znamo prema zabilježenome gostovanju u Ljubljani, u studenome 1899., kada mu ljubljanske gradske nadležne vlasti, od kojih je zatražio dozvolu za rad (projekcije filmova), izdvajaju za javno prikazivanje 17 od 61 raspoloživa kratka filma zbog, kako se tada to općenito formuliralo, „pikantnoga sadržaja“. ${ }^{92}$

Prvi putujući kinematografski prikazivači u Puli, po svemu sudeći, vrlo su dobro znali kamo dolaze i kakve je populacijske strukture grad, kad su već krajem 1898. nudili filmske vrpce „isključivo za muškarce“, znajući da ih

89 Kosanović, Počeci kinematografije na tlu Jugoslavije 1896-1918, 137.

90 „Max Schüler, mehaničar iz Pule (Svitava, 1872. - Boskovice, 1931.). Sa svojim projektorom Thaumatograph studenoga je mjeseca 1899. prikazivao filmove u Ljubljani. Raspolagao je sa 63 filma (prema Janezu Polajnaru [vidi bilj. 92], Max je Schüler raspolagao s dva filma manje, ukupno 61 filmom, op. a.), ali mu nadležne vlasti nisu dozvolile prikazivanje 17 filmova 'pikantnog sadržaja'. Drugih podataka o njegovoj prikazivačkoj djelatnosti nema." Kosanović, Leksikon pionira filma, 210.

91 Knežević, „Prva kinematografska prikazivanja u Ljubljani (1896-1900)“, 288.

92 „Godine 1899., od 8. do 11. studenoga, gostuje u Ljubljani Max Schüler, poduzetnik iz Pule, također vlasnik putujućeg kinematografa. Regionalni ured zatražio je od njega, prije početka programa, da sve filmove prijavi cenzuri. Očito je Schüler bio manje spretan od Bläsera, jer je za odobrenje pedantno predao popis svih snimaka koje namjerava projicirati. Od namjeravanoga programa odobreno mu je 44 slikafilmova, a 17 pikantnih slika predviđenih za muške večeri (Herrenabende) odbijeno mu je. Poduzetnik je prema tome od svih filmova koje je sa sobom donio, imao više od četvrtine onih koje cenzor nije odobrio za javno prikazivanje.“ Janez Polajnar, Pfuj! To je gerdo!: k zgodovini morale na Slovenskem v dobi meščanstva, Celje 2008., 152. 
je vrlo isplativo vrtjeti - prije svega, mladim došljacima, potentnim ročnicima i frustriranim proleterima - u vojnom gradu „samo za izabrane gledatelje“. Sve je počelo prvim filmskim 18-sekundnim Poljupcem (The Kiss) May Irwin i Johna Ricea, „koji je 1896. snimio za Edisona (Thomas Alva Edison) bivši fotograf Edmond Khun, prema u to vrijeme popularnoj kazališnoj predstavi 'Udovica Jones' (The Widow Jones) koja je igrala na Broadwayu. Kritičar Herbert S. Stone 15. lipnja 1896., u novinama Chicago Tribune, napada ovaj film zbog prizora poljupca. Ovu scenu on je okarakterizirao kao 'bestijalnu', ‘apsolutno degutantnu’, zaključujući da ‘takve stvari zahtijevaju intervenciju policije'. Posebno naglašava kako je prizor tog 'teško podnošljivog prianjanja usta na usta' koje se ponavlja čak tri puta, uvećan do 'gargantuovskih proporcija'“" ${ }^{93}$ No, Europljanima takvi prizori nisu bili degutantni. Premda su prvi erotski filmići (2-3 minute) bili gotovo neerotični, uglavnom nepotpuno razodjevenih djevojaka, iz današnje perspektive ustvari bili su krajnje moralni, puritanski, čedni i pristojni (ali samo do prijelaza stoljeća), puljski su ih mornari, proleteri i usamljenici (naročito oni koji nisu bili solventni za bludilišta ${ }^{94}$ bez sumnje rado gledali. „Posebno su bili omiljeni filmovi koji su prikazivali žene u različitim stadijima skidanja: 'U garderobi', 'U njenom budoaru', 'U budoaru moje gospođe’, 'Kod maserke', 'Nevjestina soba'. U skidanju se nikada nije išlo dalje od košulje. Ali u doba kad je čak i pogled na čarapu bio šok, smatralo se da dama odjevena samo u donje rublje predstavlja vrhunac skandala. (...) Prvi katalozi francuskih kompanija sadržavali su stotine naslova koji su ukazivali na neku vrst svlačenja: 'Svlačenje modela', 'Lijeganje Yvette i Pierreuse', 'Lijeganje nevjeste' (ponovljeno nekoliko puta s različitim glumicama), 'Indiskretne subrete', 'Ženska svlačenja' i dr. Sa dolaskom novog stoljeća došlo je nešto novo, ti su filmovi zamijenjeni potpunim strip-tease filmovima. Proizvodna formula bila je ista, ali sada se pokazivalo ono što je obećano." ${ }^{\text {95 }}$

Mahom su svi u Pulu pristigli putujući kinematografi (i njima slični uređaji za projiciranje gibljivih slika) pored regularnih projekcija za sveko-

93 Milan Ranković, Seksualnost na filmu i pornografija, Beograd 1982., 97.

94 „Potkraj 19. i početkom 20. stoljeća, pa do 1918. u Puli je bilo otvoreno desetak javnih kuća (otvarale su se jedna za drugom, ali ih je istodobno radilo najviše sedam), od kojih su se do 1919. zadržale svega četiri. Njihov je broj teško utvrditi i često se mijenjao (najviše ih je bilo 11 u razdoblju 1914. - 1915.). Neke su se otvarale, neke, pak, zatvarale, premještale ili su mijenjale vlasnike i adrese (najčešće kućne brojeve). Naravno, njihovo otvaranje, uređenje, kućni red, boravak i djelatnost bio je reguliran Pravilnikom o javnim kućama koji je do početka 20. stoljeća morao imati svaki grad koji je imao javne kuće." Darko Dukovski, Istra 'spod ponjave: povijesni erotikon istarski od kraja 19. do počttka 21. stoljeća (dalje: Istra 'spod ponjave), Pula 2016., 284-285.

95 Zorislav Ugljen (prir.), Erotika na filmu, Zagreb 1967., 11 i 14. 
liko općinstvo organizirali i specijalne predstave (po pravilu zadnja večernja prikazivanja) za znatiželjnu i obnaženih ženskih tijela željnu mušku publiku. Specijalne predstave „isključivo za muškarce“ renomiranijih putujućih kinematografa javno su najavljivane i reklamirane u novinama, ali zasigurno je bilo i onih manjih kinematografa koji su (ne želeći trošiti na novinsko oglašavanje) najavljivali program (različitoga sadržaja) samo na plakatima. Putujući filmski prikazivač Čeh Karel (Carl, Karlo ili Dragutin) Lifka ${ }^{96}$ u Carrarinoj ulici podiže kinematografski šator od 30. siječnja ${ }^{97}$ do 2. ožujka $1903 .{ }^{98}$ i od 10. veljače ${ }^{99}$ najavljuje, oglašava u novinama svakoga dana (na talijanskom i njemačkom jeziku $)^{100}$ u osam sati navečer projekcije samo za odrasle muškarce (ili decentnije: samo za gospodu), popularne serate nere („crne večeri“) ili Herrenabende (doslovce, „momačke večeri“101, ili općenitije, „večeri za gospodu“), ${ }^{102}$ zbog francuske (pariške) slobodne proizvodnje nazivane i „pariškim večerima“, erotskih i sličnih filmića (još uvijek ne tvrdih tema i eksplicitnih sadržaja) ne navodeći njihove nazive. Jednako je tako, u istoj ulici, i putujući Bläserov kinematograf za Božićne blagdane iste godine, od 6. prosinca 1903. do 10. siječnja 1904., koji redovito svaku večer nakon redovitog programa projicira kratke filmove za gospodu „s izabranim, novim i pikantnim programom“103. Bläser nije štedio na promidžbi lascivnih filmića, usporedo je novinski oglašavao erotski program različitim tekstovima na talijanskom i njemačkom jeziku (s posebnom napomenom: „Gos-

96 „Karel (Karl Friedrich, Carl, Dragutin) Lifka, putujući prikazivač filmova, sin vlasnika putujuće menažerije i drugih atrakcija. S mlađim je bratom Aleksandrom (Sándorom) Lifkom 1902. u Trstu izgradio zajednički putujući Electro-bioskop Lifka koje je narednih godina prikazivao filmove u Trstu, Ljubljani, Gorici, Puli, Rovinju, gradovima Dalmacije, Mostaru, Sarajevu, Zagrebu, Novom Sadu, Subotici, Beogradu, te u Mađarskoj, Rumunjskoj itd. Braća su se 1904. razdvojila - svaki je poslovao s vlastitim putujućim poduzećem, s time što je Karel zadržao teritorije Austrije, Češke, Slovenije i Hrvatske, dok je Aleksandru prepustio istočne krajeve: Mađarsku, Slovačku, Bosnu, Vojvodinu i Srbiju. Poslije 1908. otvara stalne kinematografe u moravskoj Ostravi, Salzburgu, Linzu i Amstettenu. Živio je i preminuo u Linzu; u Salzburgu se i danas jedan kinematograf zove Lifka-Kino." Kosanović, Leksikon pionira filma, 128.

97 „Bioscopio elettrico“, Il Giornaletto di Pola, 30. siječnja 1903.

98 „Viale Carrara, Bioscopio elettrico: Oggi lunedì, 2 Marzo 1903, Ultimo definitivo giorno alle ore 8: Serata nera“, isto, 2. ožujka 1903.

99 „Questa sera incomincia un ciclo di rappresentazioni per soli signori.“, „Viale Carrara, Bioscopio elettrico: Tutte le sere alle 8 Serate nere, soltanto per signori“, isto, 10. veljače 1903.

100 Godine 1903. izlazio je samo jedan puljski dnevnik, Il Giornaletto di Pola na talijanskome jeziku, koji je oglase tiskao na talijanskom i njemačkom jeziku pa tako na oba jezika objavljuje i oglase za „crne večeri“. Tek od 15. listopada 1905. počinje izlaziti i dnevnik na njemačkom jeziku Polaer Morgenblatt te su tada, krajem 1905., pa do polovice 1906., uz Il Giornaletto i Laginjin višejezični Omnibus, Puljani imali svakodnevno na raspolaganju tri dnevnika.

101 Marija Uroić - Antun Hurm, Njemačko-hrvatski rječnik, Zagreb 2004., 358.

102 „Electro Bioscop, Jeden Abend um 8 Uhr Harren-Abend nur für Erwachsene.“, Il Giornaletto di Pola, 11. veljače 1903.

103 „Viale Carrara, Bioscop: Ogni giorno alle ore 8.30 di sera avrà luogo una rappresentazione soltanto per adulti con scelto, nuovo e piccante programma.“, isto, 3. siječnja 1904. 
poda ispod 20 godina nemaju pristupa.“). ${ }^{104}$ Jesu li gledatelji serata nera bili zadovoljni prikazanim prvim Pathéovim filmovima (u posebnom odjeljku Pathéova kataloga za erotiku stoji napomena: „Golicave teme pikantne naravi. Djeci ne treba dopuštati da prisustvuju prikazivanju tih scena“), ${ }^{105}$ početkom stoljeća najvećega svjetskog proizvođača takve vrste filmića (ali i nadolazećih žanrova), ${ }^{106}$ i je li im projicirano „ono što je obećano“ (prisilno pristojni i moralni) novinari ne izvješćuju, tako da pouzdanih izvornih informacija nemamo.

Naslućujući još veću erotsku slobodu (u početku svlačenja, a malo zatim i intimnih akcija) koja prelazi u pornografsku, najprije simuliranu mekanu, a potom i tvrđu eksplicitnu formu nije trebalo dugo čekati. „U kratkom razdoblju od 1904. do 1906. nekoliko francuskih studija proizvelo je za opću distribuciju filmove koji su očito bili pornografske prirode. U katalozima su bili grupirani pod zajedničkim naslovom 'Obijesne stvari pikantne prirode’. Započinjali su sa scenama u kadi za kupanje ili u spavaonici, a onda hitro prelazili na detaljno prikazivanje otvorene erotike. Djevojke u kadama slobodno su pokazivale i milovale svoje draži, plivale nage u ukrašenim bazenima ili se senzualno izvijale u svojim krevetima u očekivanju posjeta Vaselinusa, sladunjavog junaka koji se neprestano pojavljivao u seriji pikantnih pastiša proizvodnje Pathé. (...) U Njemačkoj vodeći imitator Francuza bio je Oskar Messter. On je započeo svoju dugu karijeru 1902. sa 'Salomom', koja je bila toliko erotična da su taj film zabranili posvuda osim u Njemačkoj. Većim dijelom, Messter se zadržavao u kupaonicama i spavaonicama kao i njegovi francuski suvremenici, ali je na scenu uveo jednog ili više promatrača čime je neugodno naglasio voajerističku prirodu ove zabave. Venis Film iz Berlina i nekoliko malih kompanija iz Beča proizvodili su otvorenu pornografiju. (...) Talijani, koji su počeli proizvoditi filmove 1905., odmah su se bacili na njima još uvijek najdraži žanr: pseudohistorijski spektakl s

104 „Bioscop viale Carrara. Der Unterfertigte verens'altet vom Freitag den 25 ab jeden Abend um 8 1/2 Uhr eine Extra-Vorstellung nur für Herren mit gewähltem, neuem pikantem Programm. Herren unter 20 Jahren haben keinen Zutritt.“, isto, 26. prosinca 1903.

105 Sadoul, Povijest filmske umjetnosti, 54 .

106 „Uspon braće Pathé, snažnijeg od dvaju konkurenata (Léona Gaumonta i braće Lumière, op. a.), dobar je primjer tih ranih godina. Nakon što su započeli rad uvozom Edisonovog fonografa i potom proizveli vlastitu kopiju njegova kinematoskopa, lukava su braća 1905. prodavala 200 kamera i projektora mjesečno, kao i 12.000 metara filma dnevno. A 1906 . već su prodavali 40.000 metara filma dnevno, producirali desetak kratkih filmova tjedno, svaki u 75 primjeraka, i bili u procesu stvaranja svjetske distribucijske mreže za svoje filmove. Agencije braće Pathé bile su 1904. otvorene u Moskvi, New Yorku i Bruxellesu; 1905. u Berlinu, Beču, Chicagu i Sankt Peterburgu; u Amsterdamu, Barceloni, Milanu i Londonu 1906. i ubrzo su se širili svijetom duž kolonijalnih ruta Indije, jugoistočne Azije, Srednje i Južne Amerike i Afrike..." Philipp Blom, Vrtoglave godine: Europa, 1900.-1914., Zaprešić 2015., 392. 
operetskim korom statista i razaranjima velikih formata (koje prouzrokuje priroda ili čovjek), odvažnim herojima i uvijek ugroženim junakinjama. Pod vidom historije bile su dopuštene sve vrste strahota - orgije, silovanja, rafinirane torture koje bi u suvremenim kontekstima bile osuđivane." ${ }^{07}$

Kinoprikazivač Salvatore Spina ${ }^{108}$ iz Trsta ${ }^{109}$ gostuje u Politeami Ciscutti početkom 1906., od 20. do 29. siječnja, ${ }^{110}$ i zatim još tri puta: od 8. do 17. rujna 1906., od 2. do 7. veljače 1909. kao kinematograf Gigante i od 25. travnja do 1. svibnja 1909. ${ }^{111}$, kada priređuje i „crne večeri“ samo za muškarce, soltanto per uomini (što ne znači da tamnih večeri nije bilo i na prijašnjim gostovanjima, samo nisu novinski najavljivane). Poput Spine u Trstu 1906., ${ }^{112}$ u Puli iste godine vlasnik stalnoga kinematografa Exscelsior Covini, pored stalnoga kina na Portarati s redovitim dnevnim repertoarom, ima i paralelne projekcije (posjedovao je, kako činjenice pokazuju, najmanje dva projekcijska uređaja) u Politeami, od 13. do 29. siječnja 1907., ${ }^{113}$ s programima „mrklih večeri“.

No, serate su nere često nailazile na nezadovoljstva i prosvjede, ne moralistički nastrojenih građana (i uvijek na moralne paske spremne Crkve), već gledatelja nezadovoljnih nedovoljno obnaženim djevojkama (poput tada redovitih kratkofilmskih provokacija: „U jednom filmu svlači se djevojka da bi se

107 Ugljen, Erotika na filmu, 16-18.

108 „Salvatore Spina (Spina-Cucumazzi), talijanski pionir filma iz Trsta (Foggia, 1863. - ?). Vlasnik putujućeg kinematografa Gigante koji je prvih godina dvadesetoga stoljeća prikazivao filmove u Italiji, Venetu, Istri i Dalmaciji (od 1905. u Dubrovniku, Splitu, Zadru, Rijeci, Puli, itd.). Ne prekidajući djelatnost s putujućim kinematografom, nastanio se 1905. u Trstu gdje je iduće godine (1906.) otvorio stalno kino, cinematografo Spina. Djelatnost je proširio i na trgovinu kinematografskom opremom, distribuciju i snimanje filmova za svoj kinematograf i po narudžbi. Do 1911. realizirao je u Trstu, kao producent, snimatelj i redatelj dvadesetak dokumentarnih i jedan (kratki) igrani film. Godine 1909. snimio je po narudžbi Slovenskoga radničkog pjevačkog društva Slavec, dokumentarni film Ljubljana (ili Slavnostni dnevi Slovenskega delavskega pevskega društva Slavec v Ljubljani) koji je dobrim dijelom sačuvan. Njemu bi se, dosta sigurno, mogao pripisati i prvi igrani film snimljen na tlu Hrvatske, 1909. u Rijeci - Napad na Narodnu banku u Rijeci, rekonstrukciju stvarnoga događaja. Nakon 1914. prebjegao je u Italiju i nastavio filmsku djelatnost u Milanu, gdje mu se krajem Prvoga svjetskoga rata gubi trag." Kosanović, Leksikon pionira filma, 200-201.

109 „U Trstu se 1905. godine nastanio pionir filma Salvatore Spina, koji je još od početka 1902. godine u Italiji prikazivao filmove u svojem putujućem Cinematografo Gigante Edison. Spina je u Trstu organizirao svoj novi Reale Cinematografo Gigante i od 2. do 20. rujna 1905. prikazao filmove u Politeami Rossetti. Zatim je počeo svoja putovanja i gostovanja u gradovima Istre, Dalmacije (i Italije), koja je nastavio i sljedećih godina usporedno s otvaranjem stalnoga kinematografa Spina u Trstu (1906.), što znači da je imao više projekcijskih aparatura." Isti, Prvi koraci filma u Rijeci: 1896-1918, 39.

110 Oglas uoči gostovanja putujućega kinematografa Spina: „Politeama Ciscutti - Per domani sera, sabato, è annunciata la prima rappresentazione di Spina col suo rinomato cinematografo gigante, giudicato dalla stampa italiana ed estera uno dei più perfetti che viaggi il mondo. Il programma della rappresentazione di domani contiene fra altro: Balli plastici (a colori); La recluta (scena militare umoristica); Gli effetti del vino; Minuetto lillipuziano (a colori); Boby, il cane salvatore; Venti mila leghe sotto i mari: ovvero le meraviglie delle profondità dell'Oceano, proiezione fantastica colorata (35 quadri); Da Pola a Divaccia (scena comica in uno scompartimento di seconda clase); Vita di marinaio; La sirena (fantasia a colori); - in chiusa si darà: Brigantaggio moderno, in automobile e bicicletta.“ „Politeama Ciscutti“, Il Giornaletto di Pola, 19. siječnja 1906.

111 Kosanović, Kinematografske delatnosti u Puli, 112-113.

112 Isti, Trieste al cinema, 80-81.

113 „Politeama Ciscutti“, Il Giornaletto di Pola, 13. i 29. siječnja 1907. 
okupala u rijeci. Ali, prije nego što će biti naga dojuri vlak i sakrije je. Neki se novinar žalio: Kad će napokon vlakovi kasniti!“114) ili preblagim pohotnim filmićima (koje su vidjeli u obnaženijim, izazovnijim i tvrđim varijantama). U Puli nailazimo na novinski zapisana negodovanja publike (tko zna koliko je bilo takvih nezapisanih prosvjeda) za gostovanja Covinijeva kinematografa i kinematografa Spine u Politeami. Nezadovoljni muški posjetitelji, mahom mornari, ročnici, ležerno odjeveni časnici, proleteri na privremenom radu, usamljenici $^{115}$ i ostali znatiželjnici, željni sočnijih scena, negodovali su 29. siječnja 1907. na mekoću filmskoga repertoara: „Sinoć su gledatelji s galerije Politeame Ciscutti zviždali za vrijeme predstave jer najavljeni pikantniji dio programa nije bio dovoljno pikantan. Istina, svatko je gospodar svojega aplauza i zviždanja ako mu nešto nije najbolje po volji, ali nepristojnim ispadima nije mjesto ni izvan kazališta."116 Slično je bilo i dvije godine poslije, 29. travnja 1909., na gostovanju kinematografa Spine, kad su već austrijske cenzorske škare počele rezati ionako kratke erotske filmiće: „Oglas je sinoć privukao u Politeamu Ciscutti mnogobrojne muške gledatelje dio kojih je, po njihovome ukusu razočaran programom, izviždao pojedine projekcije kad su im izgledale nepotpune. Predstava cijeloga programa, zbog policijski osakaćenih dijelova, trajala je manje od jednoga sata." ${ }^{117}$

Brojni su, najavljeni i nenajavljeni, putujući kinematografi na svojim gostovanjima i proputovanjima pored uredovnih, uobičajenih filmskih repertoara nudili i specijalizirane erotske (ili pionirske pornografske) kratke filmove po svim gradovima Europe, pa tako i Puli obližnjim većim gradovima Trstu ${ }^{118}$, Ljubljani119, Rijeci, Zagrebu, Zadru, Splitu... Međutim, Pula je zbog svojega mornaričkoga i vojnoga statusa, militantne urbanosti,

114 Belan, Sjaj i bijeda filma, 58 .

115 „Kinematografska serata nera nije prošla posve mirno. Neki promatrač s galerije, koji je po svaku cijenu htio na sebe svratiti pozornost u kazalištu, cijelo je vrijeme za trajanja projekcije nesmetano zviždao, no nitko nije znao je li to iz pretjeranoga ili nedovoljnoga zadovoljstva...“ „Politeama Ciscutti“, Il Giornaletto di Pola, 26. siječnja 1907.

116 „Politeama Ciscutti“, isto, 30. siječnja 1907.

117 „Politeama Ciscutti: Serata nera!“, isto, 30. travnja 1909.

118 U Trstu, gradu bogate kinematografske zabave, prvo je stalno kino (Cineografo Americano) otvoreno još 12. kolovoza 1905. Kosanović, Trieste al cinema, 82.

119 Uzgred, Ljubljana prvo stalno kino dobiva zaslugom i u vlasništvu Puljanina Antonija Deghenghija godinu dana poslije Pule, 26. svibnja 1907. „Antonio Deghenghi, Talijan iz Istre (Pula, 1858-?), poduzetnik i poslovan čovjek koji se krajem 19. stoljeća nastanio u Ljubljani. Gradeći novu zgradu (1906., na uglu Dunajske i Sodne ceste) predvidio je i projekcijsku salu u kojoj je svibnja 1907. otvoren prvi stalni kinematograf u Ljubljani, kino Edison. Deghenghi je i dvije godine kasnije uložio sredstva u otvaranje ljubljanskog kinematografa Ideal.“ Isti, Leksikon pionira filma, 53. 
alkoholizma i poprilično slobodne seksualnosti (spontane i kupljene) $)^{120}$ bila specifična pojava.

Premda se ugarska Rijeka filmski i kinematografski razvijala usporedo i poput austrijske Pule (manje-više isti putujući kinematografi mahom iz Trsta posjećuju oba grada s podjednakim filmskim programom), imala je prosječno manje, koliko bilježe riječki dnevnici i tjednici (prema istraživanjima Dejana Kosanovića i Nane Palinić) ${ }^{121}$, serata nera od Pule, ali sa sličnim gledateljskim reakcijama: „Sinoć je bila u kinu Fenice zadnja predstava - 'crna predstava'; gospođice isključene; samo za muškarce! Navalilo je preko 2.000 ljudi uz pohlepu da vide tko zna kakove pikanterije. No, pošto su slike bile prilično 'pristojne', to se je masa vrlo ražestila, pak piskanju i vikanju nije bilo ni kraja ni konca. Publika, kao što se to obično događa kod ovakovih 'crnih večeri' razočarana je izašla iz kazališta."122 Ili još žešćim: „Kako filmovi nisu bili na razini najave i reklame, nezadovoljnici su se okomili na projekcijski aparat, koji je u posljednji čas spašen.“123 Dakako, ni Pula ni Rijeka nisu se mogle mjeriti s pet-šest puta napučenijim i većim Trstom, pomorskim, brodograđevnim i trgovačkim središtem Austro-Ugarske Monarhije sa snažnom kinoprikazivačkom mrežom putujućih kinemato-

120 „Pula je početkom 20. stoljeća bila vrlo živ grad, bizarnih noćnih scenografija i životnih performansa, noćnih pjevača (cantadori notturni), skitnica, pijanih građana i posvađanih parova. U ulicama Donjeg grada, u trenutku kada se pali plinska rasvjeta, počinje jedan drukčiji život grada. Pijane, drske i prostačke pjesme iz gostionica u ulicama Abbazia, Barbacani, Tradonico, Kandler i Prolazu S. Niccolo razlijegale su se i miješale sa psovkama i nadvikivanjem na svim jezicima »Dvojne Monarhije« (...)." Dukovski, Istra 'spod ponjave, 291. „Odnos građana Pule, pak, prema javnim kućama i sve većem broju prostitutki nije bio idiličan, bez obzira na veliku posjećenost, jer pritužbi stanovnika starog dijela grada na noćnu galamu i prostačenje u »sitne sate« nije nedostajalo. No, to je bio problem koji se nije mogao razriješiti jer nije postojalo volje za njegovo rješenje, pa se ondje malo toga moglo učiniti, izuzev čestih izražavanja nezadovoljstva nemoralnošću ponašanja prostitutki i njihovih klijenata. (...) Čak je i uredništvo pulskih novina L'Eco di Pola potkraj 1896. godine apeliralo na roditelje mladih djevojaka da im ne dopuste noćne »promenade«, kada je poznato što u noćnim satima djevojke mogu raditi izvan kuće. A ni Crkva nije previše protestirala, kao ni desetljeće poslije, shvativši da je svaka akcija protiv prostitucije osuđena na neuspjeh." Isto, 297.

121 Podrobnije o putujućim kinematografima i prvim stalnim kinima u Rijeci: Kosanović, Prvi koraci filma $u$ Rijeci: 1896-1918., 21-52; Nana Palinić, „O povijesti riječkih kinematografa: Cinematografo Argentina, Teatro Minimo, Teatro Argentina, Teatro Pallas, Centrale, Garibaldi, Kvarner", Dometi, 7-12, 1995., 169-180; ista, „O povijesti riječkih kinematografa: Teatro Fenice, Cine-teatro Fenice, kino Partizan, kino Teatro Fenice“, Dometi, 1-6, 1996., 167-188; ista, ,O povijesti riječkih kinematografa: Teatrino Cappuccini, San Giorgio, Beograd, Croatia“, Dometi, 7-12, 1996., 196-208; ista, „O povijesti riječkih kinematografa: od prvih filmskih projekcija do otvaranja prvog stalnog kinematografa 1896-1906.“, Dometi, 1-6, 1997., 7-34; ista, „O povijesti riječkih kinematografa - prvi stalni kinematografi: Salone Edison, Elektra, Progresso“, Dometi, 7-12, 1997., 97-1 10; ista, „Sušački kinematografi“, Sušačka revija, 17, 1997., 55-64; ista, „O povijesti riječkih kinematografa: Cinematografo Olimpo, Margherita, Urania, Armonia“, Dometi, 1-6, 1999., 59-68; ista, „O povijesti riječkih kinematografa: Grande Cinematografo Parigi, Teatro Minimo, Carlo Goldoni, Grande Cine-Varieta, Parigi, Impero, Viševica“, Vjesnik Državnog arhiva u Rijeci, 43-44, 2002., 333-350.

122 Novi list, 22. kolovoza 1906., u: Ivan Flod, „Počeci kinematografije na Rijeci i Sušaku“, Filmska kultura, 97, 1974., 94.

123 La Bilancia, 22. kolovoza 1906., u Nana Palinić, „O povijesti riječkih kinematografa: od prvih filmskih projekcija do otvaranja prvog stalnog kinematografa 1896-1906.“, 34. 
grafa i brojnim stalnim kinima, gdje su „mrkle večeri“ erotskih i pionirskih pornografskih filmova tih godina bile svakovečernja pojava.

U Zagrebu, u kojem je zabilježeno, koliko je zasad istraženo, manje erotskih večeri od Pule i Rijeke, očito su imali nedaća s krišom uteklim adolescentima na „crne predstave“, čim su pikantne kratke filmove pedagoški oglašavali: „samo za gospodu, dječaci nemaju pristupa“124, a bili su i blažega erotskog naboja budući da napomena „pristup samo odrasloj gospodi i gospodjami“"125 nije bila uobičajena u ostalim gradovima, gdje su eksplicitniji filmovi bili namijenjeni isključivo muškoj čeljadi; u Puli su pak gledateljice i gledatelji imali odvojene specijalizirane projekcije. Zadrani nisu ni bili u mogućnosti vidjeti obnažena ženska tijela na filmskome platnu: „Poznato nam je da su takve ekskluzivne 'crne predstave' 1903. zabranile zadarske vlasti, što je izazvalo prosvjedovanje građanstva, jer su u ostalim mjestima (kao u Gorici, Rovinju, Puli) bile odobrene. 'Ništa skandaloznog - žali se jedan Zadranin - jer se iste scene pružene svima na uvid mogu vidjeti na poštanskim dopisnicama u svim papirnicama.' Bilo je i kasnije filmova uz koje je stajao oglas: Samo za odrasle. Ali ti su bili veoma rijetki..." ${ }^{26}$ U Splitu su pak čedni i nimalo provokativni filmovi (naspram prvih pornića i erotskih filmića u Puli) na udaru dežurnih crkvenih moralista koji su redovito prijavljivali gradskim vlastima svaki obnaženi ženski gležanj na filmskom platnu: „Ovakva šta nijesmo vjerovali da se može prikazivati u Spljetu u prisuću svećenika, većinom djece obojega spola i mnoge druge gospode. Pitamo svakoga, da li se može ovakav nemoralan komad u javnosti predstavljati i na onaj način korumpirati uzdanicu našu, mladež našu? Što rade poznati faktori i cenzura. Prosvjedujemo i pozivljemo vlasti da paze pojedine komade, koji se daju u kinematografu Josipa Karamana..." ${ }^{27}$

Uspoređujući pojavu bestidnih filmića u austro-ugarskoj prikazivačkoj kinematografiji, Pula je naspram spomenutih gradova (a vjerojatno i mnogih drugih, osim onih sličnoga vojnoga ustroja, života, hedonizma i zabava) prednjačila u projiciranju „pikantnih filmova“, što se pripisuje toleranciji gradskih i mornaričkih nadležnih vlasti i institucija (dobro poznavajući socijalnu strukturu vojnoga grada prepunoga prepotentnih mladih mornara i

124 Kosanović, Počeci kinematografije na tlu Jugoslavije 1896-1918, 138.

125 Ivo Škrabalo, 101 godina filma u Hrvatskoj, 1896-1997.: pregled povijesti hrvatske kinematografije (dalje: 101 godina filma u Hrvatskoj), Zagreb 1998., 29.

126 Kečkemet, Počeci kinematografije i filma u Dalmaci̋i (1897-1918), 115

127 Isto, 116. 
radnika, čija se pohota jeftinije gasila na filmskom platnu negoli u skupim bordelima $^{128}$ ili s nešto jeftinijih ilegalnim prostitutkama ${ }^{129}$ ) u propuštanju slobodnijih erotskih i kasnijih pornografskih slika (tako tada zvanih lascivnih filmića), za razliku od oštrice cenzorskih škara ostalih gradova (primjerice Ljubljane, gdje su Johann Bläser i Max Schüler bili stalno „na piku“ ljubljanskih cenzora ${ }^{130}$, Zadra ili Splita). Takva praksa serata nera i Herrenabendea nastavljena je i kasnije, u prvim stalnim puljskim kinematografima. ${ }^{131}$

Ne navodeći sve zasad poznate putujuće kinematografe koji su u Pulu donosili bludne i razvratne filmiće, kako bi nakratko smirili prepotentnu (mušku) puljsku populaciju i razveselili oženjene mužjake, treba svakako još spomenuti i veseloga Antonija Violića (Violicha) ${ }^{132}$ iz Pule, vlasnika (putujućega) kinoprojektora Pathé, posredno zaslužnoga za prvo stalno kino u Splitu, najtrajnije (još uvijek djelatno) kino u Hrvatskoj, kino Josipa Karamana $^{133}$. Violić nije obožavao kinematografski posao: „Izgleda da je vlasnik kinematografa više volio jelo i piće nego organizirani rad, pa je nakon te ljetne sezone 1906. godine prodao kinoprojektor svom novom kompanjonu

128 „Pula je od 1906. do 1914. s više od 58 tisuća stanovnika, uključujući i preko 16 tisuća vojnika, od kojih većim dijelom mornara, imala dovoljno legalnih javnih kuća, uvijek sa 60-ak do 80-ak prostitutki, od kojih je čak trećina živjela izvan bordela. Početkom rata broj se prostitutki gotovo udvostručio, pa su otvorene najmanje još dvije javne kuće. Sobe su uglavnom pronašle u ulicama u kojima su radile, pa su pokatkad mogle posao »odnijeti« kući. Živjelo ih je i po nekoliko u malim sobicama, jer su tako dijelile troškove stanovanja, pa su i mogle nešto i zaraditi." Dukovski, Istra 'spod ponjave, 288-289.

129 „Policiji i vojnim vlastima najviše je problema zadavala ilegalna prostitucija, ponajprije stoga što je ova vrsta zakonom zabranjene djelatnosti, uz spolne bolesti, bila povezana s kriminalnim podzemljem. Bila je jeftinija od bordelske prostitucije, pa stoga i raširenija, a zbog svoje tajnosti nedostupna liječničkom nadzoru. Stoga su ilegalnu prostituciju smatrali glavnim izvorom zaraze spolnim bolestima, na koje su posebice bile osjetljive vojne postrojbe." Isto, 293.

130 Usp. Janez Polajnar, „Prihod za sramežljivost in javno nravnost grobo škodljivih filmov na Slovensko“, Časopis za kritiko znanosti, domišljijo in novo antropologijo, 220, 2005., 11-30, naročito poglavlje „Moški večeri, pikantni filmi...", 20-27.

131 „Tradicija održavanja predstava s pikantnim programom nastavila se i u narednom razdoblju osnivanja prvih samostalnih kinematografa. Tako je 1907. kino Edison u Puli jedino oglašavalo crne večeri- samo $z a$ odrasle (serate nere - per solo adulti), jer je to osiguravalo dobre prihode. Tek oko 1910. započinje na teritoriji Austrougarske zabranjivanje ovakve zabave, što je crne večeri potisnulo u ilegalu, ali ih nije potpuno iskorijenilo..." Kosanović, Počeci kinematografije na tlu Jugoslavije 1896-1918, 138.

132 „Antonije Violić, iz Pule, putujući prikazivač filmova. Posjedovao je kinoprojektor Pathé i 1906. prikazivao je filmove u Kavani na obali u Splitu. Partner mu je bio kasniji pionir filma iz Splita, Josip Karaman, a kinooperater Viktor Wolf. Krajem 1906. Violić je kinematografsku aparaturu prodao Karamanu, koji je početkom 1907. otvorio prvi stalni kinematograf u Splitu.“ Kosanović, Leksikon pionira filma, 235.

133 „Josip Karaman, vlasnik kinematografa i snimatelj (Split, 18. IX. 1864 - Beč, 11. VII. 1921). Trgovac, svestranih interesa, jedan je od utemeljitelja gradske glazbe i opernih gostovanja u Splitu. Godine 1906. otkupio je kinoprojektor jednoga putujućega kinematografa, samostalno priređivao kinopredstave, a 1907. otvorio Grand Elektro Bioskop, prvi stalni kinematograf u Splitu, u kojem se repertoarom i natpisima na hrvatskome suprotstavljao iredentističkim tendencijama. Potom, 1910. nabavio je filmsku kameru i snimao aktualne događaje koje je prikazivao u svojem kinu. Te je godine (21. kolovoza) snimio reportažu o sokolskome sletu u Splitu, zatim proslavu proglašenja Crne Gore kraljevinom, a 1911. svesokolski slet u Zagrebu te reportaže o procesiji sv. Duje i sprovodu gradonačelnika Vicka Mihaljevića. Pionir hrvatske kinematografije, Karaman se potom više nije bavio filmom.“ „Karaman, Josip“, Hrvatska enciklopedija, http://www.enciklopedija.hr/Natuknica.aspx?ID=30399. 
Karamanu..."134 Violićev (puljski) originalni (kasniji Karamanov) kinoprojektor Pathé sačuvan je, čuva se u Muzeju grada Splita. ${ }^{135}$

„Pojava prvih filmova pornografskog karaktera teško se može utvrditi; oni nisu nastajali u okviru institucionalizirane, dominantne kinematografije, niti su prikazivani u odgovarajućoj kino-mreži (zbog njezine ovisnosti o svim državnim i državotvornim institucijama). Međutim, upravo kao posljedica zabrana na području spolnosti i potrebe za pornografskim filmom zbog njegove erotske djelotvornosti, pornografski se film javlja vrlo rano - $u$ alternativnoj kinematografiji, i to njezinom najanonimnijem pa i najopskurnijem vidu koji vrlo često djeluje ilegalno; često pod nadzorom 'podzemlja' (ponekad vezanoga uz prostituciju), proizvođen od raznih 'odbačenika' filmske industrije ili diletanata (u zemljama s nešto liberalnijim pogledima, odakle se krijumčari u druge), uz male honorare, na niskoj realizacijskoj razini, većinom kraćeg trajanja... Takve okolnosti proizvodnje i plasmana, kao i ilegalnost same djelatnosti, razlog su što je golema većina starijih pornografskih filmova izgubljena. "136 Nije nimalo slučajno da u Puli nije zabilježena ni jedna kinoprojekcija, tada zvana kinematografska predstava, Antonija Violića, kao ni, 1899. i kasnijih godina, mehaničara Maxa Schülera, dvojice Puljana koji su imali dozvole za prikazivanje filmova i vlastite kinoprojektore (Pathé i thaumathographe) te priređivali navedene kinematografske predstave u Splitu ${ }^{137}$ i Ljubljani. Čini se malo vjerojatnim ili gotovo nevjerojatnim da jednako nisu učinili i u svojemu gradu, u Puli, ali kako novine to nisu zabilježile, ne postoji arhivska građa, nema sačuvanih plakata ni letaka, nema oralne ni epistolarne povijesti o njihovim kinoprojekcijama, premda ne treba nimalo sumnjati da su, s obzirom na to da su posjedovali kinoprojektore, prikazivali u privatnim aranžmanima, u zamračenim sobama austrijskih vila, „unutar zidova bordela i privatnih klubova“138 kojekakve kinematografske

134. Kečkemet, Počeci kinematografije i filma u Dalmaciji (1897-1918), 91.

135 „U zbirci se također nalaze i vrijedni primjerci foto i kino opreme među kojima se ističe projektor prvog splitskog kina The Grand Phono Biograph poznatijeg danas kao kino Karaman koje je otpočelo radom 1907.“, http://www.mgst.net/zbirke/.

136 Ante Peterlić, „Pornografski film“, Filmska enciklopedija, sv. 2 (L-Ž), 351-352.

137 „Prema usmenim podacima pokojnog Marija Petrušića, koji je od najranijih dana pomagao Josipu Bepu Karamanu u njegovim brojnim poslovima, saznao sam (Duško Kečkemet, op. a.) da je u Splitu 1906. godine gostovao Josip Violich iz Pule i zajedno s Bepom Karamanom prikazivao filmove na otvorenom, u vrtu na tzv. Savovom bedemu, nedaleko od današnje Vid Morpurgove poljane. Violich je došao u Split kao putujući prikazivač filmova u doba kad su putujuća kina bila uobičajena širom Europe.“ Bogdan Žižić, Josip Bepo Karaman i Split njegova doba, Zagreb 2012., 64 
zabave na zatvorenim (pornografskim) ${ }^{199}$ ili poluzatvorenim (erotskim) veselicama, što se pouzdano zna za Maxa Schülera (17 filmova koje je prijavio, a tho zna što sve nije prijavio, bilo je „pikantnoga sadržaja“), a vjerojatno ni veselom Violiću takve projekcije nisu bile strane. Ovi puljski primjeri, kakvih je zasigurno bilo još jer su kinoprojektori bili dostupni, kako vidimo, i srednjem gradskom sloju, potvrđuju kako su novinski zabilježene putujuće kinematografske i gradske projekcije u kinima samo dio ukupnih filmskih događanja u svakome značajnijem europskome gradu, samo fragmentarni (službeni) zapisi cjelokupne kinematografske povijesti nekoga grada, čiju cjelokupnu filmsku povijest nikada nećemo u potpunosti otkriti (napose ne onu intrigantniju, zabranjenu, tajnu, privatnu), pa tako ni ovu puljsku.

\section{Kino Edison (1906. - 1907.) - erotsko kino}

Dopunska kinematografska djelatnost trgovca i mešetara Ivana Tominca nije bila dugoga vijeka: „Doznajemo ovih dana da je kinematograf Tominz kraj kioska Priora prodan drugoj osobi koja ga kani uskoro otvoriti gledateljstvu s velikim novitetima. ${ }^{\text {“140 }}$ Paviljon na Tržnici, kod Priorina kioska, skromno je 6. listopada 1906. „, raznolikim programom“1141 (istoga dana kad je Covini svečano otvorio čekaonicu u kinu Excelsior) promijenio natpis kina Internazionale u kino Edison (uvijek jednaki nazivi kina, poput perpetuiranoga Edisona, koji se pojavljuje svuda, diljem svijeta u više milijuna primjera, u prva dva desetljeća 20. stoljeća ne samo da su sumanuto nekreativni već su zbunjujuće ponavljajući, kao da su kinematografski zatupljeni vlasnici namjerno htjeli izazvati što je moguće veći metež, nered i pomutnju) nepoznata vlasnika. Treće stalno kino u Puli (u improviziranoj kinodvorani koju Il Giornaletto naziva teatrino di proiezioni cinematografiche Edison) i četvrto u današnjoj Hrvatskoj novi je neznani posjednik, poznavajući poprilično slobodnu seksualnost grada, ${ }^{142}$ otvorio potpuno drugačijem gradskom, socijal-

139 „Postojali su od samog početka kinematografije i filmovi s izrazito pornografskim značajkama, ali ti su obično prikazivani samo u zatvorenim krugovima, pa nisu bili podložni ni službenoj ni javnoj cenzuri.“ Kečkemet, Počeci kinematografije i filma u Dalmaciji (1897-1918), 115.

140 „Cinematografo Tominz“, Il Giornaletto di Pola, 22. rujna 1906.

141 „Riapertura“, isto, 7. listopada 1906

142 Iz zabrinjavajućega broja spolno oboljelih (napose sifilitičara), mnoštvo legalnih prostitutki i promjenjiva broja ilegalnih prostitutki početkom dvadesetoga stoljeća, razvidno je prvo: seksualni život Puljana bio je vrlo živ i intenzivan, drugo: broj povremenih, honorarnih i ilegalnih (tajnih i spolno zaraženih) bludnica (noćnih leptirica, farfalline notturne, ili samo farfalline, kako su im po ulicama i trgovima dobacivali alkoholno raspoloženi Puležani i prepotentni mornari) bio je najvjerojatnije veći od profesionalnih (koje su dva puta tjedno bile u ginekologa na redovitoj kontroli i na umu imale „Naputak za čuvanje od spolnih bolesti“) i treće: pored vojnoga i alkoholnog grada, Pula je zacijelo slovila i za grad bluda (sve zajedno pučki rečeno: grad mornara, pijanaca i kurvi). 
nom i klasnom sloju Puljana od onoga na Portarati (kino Excelsior), prije svega mornarima (ročnicima), siromašnijem sloju, radništvu (osamljenim proleterima) i lumpenproletarijatu.

Komercijalne jeftine komedije, prvi vesterni, erotski filmići obnaženih djevojaka koje su „slobodno pokazivale i milovale svoje draži“ te mekani i pionirski tvrdi pornići bili su glavni magnet kupnje ulaznica za kino Edison. „Naime, veoma važan dio repertoara kinematografa Edison bile su 'crne večeri’. O tome piše u novinskim vijestima, a Edison objavljuje i posebne oglase za te 'crne večeri', što dokazuje komercijalni uspjeh ovih vrsta filmskih predstava. Najvjerojatnije je većinu posjetitelja ovih 'crne večeri' u kinematografu Edison osiguravao puljski garnizon, ali računalo se i na druge slojeve gledatelja. (...) U Austrougarskom Carstvu ova je (1907.) godina bila vrlo pogodna za održavanje 'crnih večeri'; već poslije 1908. započinje stroža kontrola i zabrane predstava 'samo za gospodu', da bi kasnije bile potpuno obustavljene." ${ }^{143}$ Prema objavljenim oglasima kina Edison tijekom 1907. u novinama, češće nalazimo Herrenabende u Tagblattu s popisom erotskih filmova na programu (primjerice: „Kino Edison pokraj Tržnice. Program Herrenabende: 1. 'Francuska nastava', 2. 'Na obali ribnjaka', 3. 'Zabranjeno kupanje', 4. 'Kako dama naplaćuje kamatu', 5. 'Glupost ne zna za godine', 6. 'Radoznalost u kupaonici'. Cijene ulaznica: I. mjesto 60 novčića, II. 40 novčića, III. 20 novčića“"144; „Kino Edison pokraj Tržnice. Program Herrenabende: 1. 'Djed Mraz', 2. 'Pustolovni doručak', 3. 'Ptica kradljivica', 4. 'Svježe obojano““145; „Kino Edison pokraj Tržnice. Program Herrenabende: 1. 'Tuširanje na kiši', 2. 'Tržnica roblja', 3. 'Ples u stražarskoj kućici', 4. ‘Šumska nimfa', 5. 'U haremu', 6. 'Kabina za kupanje', 7. 'Igre na ljuljački’, 8. 'Poslije kupanja', 9. 'Okupane ljepote'“146) negoli serate nere u Il Giornalettu, gdje su samo najave „crnih večeri“ (,Kino Edison, kiosci Priora pokraj

143 Kosanović, Kinematografske delatnosti u Puli, 44-45.

144 „Chinematograph Edison nächst der Markthalle. Programm der Herrenabende: 1. Französischer Unterricht-2. Am Ufer des Teiches - 3. Verbotenes Bad - 4. Wie Madame ihren Zins bezahlt - 5. Alter schützt vor Torheit nicht - 6. Die Neugierde im Bade. Eintrittspreise: I. Plaz 60 Heller, II. 40 h, III. 20 h.“ Polaer Tagblatt, 19., 20., 22., 23. i 24. ožujka 1907.

145 „Morgen Sonntag, 31 März, Montag, 1. April und Dienstag, den 2. April: Kinematograph Edison nächst der Markthalle. Programm der Herrenabende: 1. Santa Claus, 2. Abenteuerliches Frühstück, 3. Vogeldiebe, 4. Frisch angestrichen. Eintrittspreise: I. Plaz 60 Heller, II. 40 h, III. 20 h.“ Polaer Tagblatt, 30/31. ožujka 1907.

146 „Von heute Montag, den 8. bis inkl. 10. April: Kinematograph Edison nächst der Markthalle. Programm der Herrenabende: 1. Regendouche, 2. Sklavenmarkt, 3. Tanz im Schildhaus, 4. Waldnymphen, 5. Im Harem, 6. Die Badekabine, 7. Die Schaukelpartie, 8. Nach dem Bade, 9. Die badenden Schönheiten. Eintrittspreise: I. Plaz 60 Heller, II. 40 h, III. 20 h.“ Polaer Tagblatt, 8. travnja 1907. 
Tržnice, svake večeri od 6 do 9 serate nere, samo za odrasle“ $)^{147}$, što jasno pokazuje kome je kino bilo namijenjeno: prije svega mornaričkoj i vojnoj populaciji (službeni jezik u mornarici bio je njemački) koja se tada našla u Puli (na odsluženju vojnoga roka ili u vojnoj službi). Dostignuvši potrebnu publiku, koja je djelotvornom i brzom usmenom predajom (po vojarnama, tvrđavama, mornaričkim školama, ratnim brodovima) reklamirala erotski program kina Edison, oglašavanje programa u novinama više nije bilo nužno (dovoljni su bili plakati), tako da nam repertoar erotskih filmića, osim onih objavljenih u Tagblattu, nije poznat.

Tek otvorena dva stalna puljska kina, rjeđe građanski Excelsior, mnogo češće i redovitije radničko-mornarički Edison, imaju na programu „crne večeri“ „samo za gospodu“ te su potpunoma slobodno projicirala erotske i prve pornografske filmiće do 1908., kad austro-ugarske cenzorske vlasti postrožuju kriterije erotske slobode, a od 1912. potpuno zabranjuju prikazivanje filmova „ako griješe protiv pristojnosti i dobrih običaja“148. Tih se godina početaka masovnoga otvaranja kinodvorana najvećem francuskom proizvođaču razodjevenih i erotskih filmova Pathé pridružuje i domaći, austrijski Saturn Film, ${ }^{149}$ producentska kuća isključivo lascivnih gibljivih slika. „Austrijski Saturnovi filmovi leže negdje između erotike i pornografije. Povijest te produkcije usko je povezana s osnivačem, fotografom Johannom Schwarzerom. ${ }^{150}$ Nakon iskustva s erotskom fotografijom, Schwarzer je osnovao tvrtku oko 1906. kako bi opskrbio gladno tržište novom hranom, erotskim filmovima. Proizvodi njegove produkcije premostili su jaz između

147 „Cinematografo Edison, chioschi Priora vicino al Mercato, ogni sera dalle 6 alle 9 serate nere, per solo adulti“, „Cinematografo Edison“, Il Giornaletto di Pola, 19., 20. i 22. ožujka 1907.

148 „Naredba Ministarstva unutarnjih poslova u dogovoru s Ministarstvom za javne djelatnosti od 18. rujna 1912. o predviđanju javnih kinematografskih prikazivanja. (Austro-Ugarska vlada, članak 17., točka 1.)“, Kosanović, Kinematografske delatnosti u Puli, 71, bilj 48. „Naredba je precizirala tko i pod kojim uvjetima može prikazivati film, a posebno su detaljni propisi o cenzuri filmova. Zabranjeno je oglašavanje večeri za gospodu (ali ne i prikazivanje), a u svakoj dvorani su morala biti rezervirana po dva mjesta za policijske kontrolore predstava." Dejan Kosanović, Prvi koraci filma u Rijeci: 1896-1918., 47.

149 Usp. Michael Achenbach - Paolo Caneppele - Ernst Kieninger, Projektionen der Sehnsucht. Saturn: Die erotischen Anfänge der österreichischen Kinematografie, Wien 1999.; Michael Achenbach - Thomas Ballhausen - Nikolaus Wostry, Saturn-Filme 1906-1910: Die erotischen Anfänge der österreichischen Kinematografie, Wien 2009.

150 Johann Schwarzer (1880. - 1914.), austrijski fotograf, filmski redatelj i producent, pionir erotskoga filma. U Beču je 1906. osnovao Saturn Film, prvu filmsku producentsku kuću u Austriji isključivo erotskoga i pornografskoga sadržaja. Do 1911. snimio je 52 filma (od kojih su pronađena i sačuvana samo 22 cijela i 9 fragmenata snimljenih filmova), koji su tržišno bili vrlo uspješni i traženi (katalozi na njemačkome, francuskome i talijanskome jeziku). Carski i kraljevski okružni sud u Beču 15. veljače 1911. zabranio je distribuciju Saturnovih filmova te naredio uništavanje svih filmskih vrpci i tiskanih materijala. Na samom početku Velikoga rata mobilizirani je Schwarzer poginuo (10. listopada 1914.) na Istočnom bojištu. Kako to već biva, ironijom ratne povijesti i Schwarzerove kobne sudbine, kasnije su upravo projekcije Saturnovih filmova po bojištima Prvoga svjetskoga rata služile za podizanje izgubljenoga morala i odvraćanje od ratnih crnih misli deprimiranih austro-ugarskih vojnika. 
francuskih erotskih 'slika' i izričito pornografskih filmova. U Saturnovim filmovima glumice su potpuno nage, čime je Schwarzer ponudio distributerima i gledateljima eksplicitnije i poželjnije proizvode od francuskih uvoznih, a definirao ih je kao umjetničke filmove (...)."151

No, pored legalne, institucionalne proizvodnje (mekanih) erotskih kratkih filmova kinematografsko je tržište bilo preplavljeno ilegalnim (tvrdim) eksplicitnim seksualnim proizvodima. „Po svoj prilici, Pathéove i Saturnove produkcije predstavljaju tek malen, samo malen dio mnogo veće produkcije amaterskih kratkih porno-filmova, od kojih je vrlo malo, ako je uopće išta, ostalo sačuvano: tek nekoliko scena nepoznatoga podrijetla s rijetkim ulomcima živahnih prizora. To su one vrste filmova kojima je unaprijed ograničeno postojanje; naime, slikopisi su uništavani nakon kratkoga tajnog života. S obzirom na široku lepezu sačuvanih slika-prizora seksualnih portreta i seksualnih aktivnost za laternu magicu (u rasponu od uobičajenih snošaja preko sado-mazohizma i grupnoga seksa do sodomije), nije teško pretpostaviti da je konzumacija sličnih slika-prizora za aparature pokretnih slika bila jednako raširena, za što postoje različiti dokumentirani primjeri do kasnih 1910-ih godina (...). ${ }^{\text {152 }}$ Ponuda tolerantnih filmova bila je 1907., pored već na tržištu poznatih francuskih pikanterija (i ilegalnih uradaka koji su kolali kinematografima), proširena novim naslovima, dovoljno obilna, vrlo zamamna i brzo dohvatljiva (tek svježe snimljeni Schwarzerovi erotski filmovi iz bečkoga Saturn Filma promptno su stizali do Pule, do nagih ženskih tijela žednih mornara i proletera u kinu Edison) $)^{153}$ te je osiguravala češće mijenjanje erotskoga programa i dobar posjet, na što je vlasnik kina Edison najviše računao. Ovaj treći (prema drugačijim kriterijima: drugi ili četvrti) stalni puljski kinematograf možemo, bez srama, prozvati prvim erotskim (ili porno-erotskim) kinom u Puli jer redovito priređuje projekcije erotskih ili ondašnjih porno-erotskih slikopisa. Kako je u prvoj polovici 1907. kino Edison već žanrovski profiliralo svoj erotski kinematografski status, a tada su u Hrvatskoj djelatna samo kina u Rijeci (Salone Edison,

151 Thomas Ballhausen, „The Saturn Film Production Company (1906-1910): From Austrian Film History to European Cultural Heritage“", Journal of Film Preservation, 85, 2011., 39.

152 Paolo Cherchi Usai, „Pornography“, The Encyclopedia of Early Cinema, ed. Richard Abel, New York 2005., 525.

153 Od 24 erotska filma snimljena tijekom 1906. i 1907. (prema naslovima filmova iz Saturnova kataloga) u Saturnovoj produkciji u puljskome kinu Edison do 8. travnja 1907. (dakle, do prve četvrtine 1907., kada je objavljen posljednji program s popisom filmova u Polaer Tagblattu) na repertoaru su se našla četiri filma: Zabranjeno kupanje (Verbotenes Bad), Igre na ljuljački (Die Schaukelpartie), U haremu (Im Harem) i Tržnica roblja (Sklavenmarkt). http://www.encadenados.org/rdc/silencio-es-oro/55-articulos/4104-saturnfilms-1906-1910. 
Progreso, Olimpo ${ }^{154}$, Puli (Excelsior, Edison) i Zagrebu (Pathé bioskop) ${ }^{155}$ koja uopće nemaju ili imaju iznimno povremeno pikantne filmove na repertoaru, to je ujedno puljsko kino Edison (što nije teško zaključiti) i prvo erotsko kino u Hrvatskoj.

Kino Edison (koje u novinama gotovo isključivo oglašava samo odjeće oslobođeni, lascivni repertoar) u „programima za odrasle“ ne zaboravlja nježniji spol, budući da gospođama i gospodičnama ulaz nije bio dopušten na programe „samo za gospodu“, pa jedanput tjedno (obično četvrtkom) priređuje i „crne večeri samo za dame“156 (jesu li imale isti repertoar ili gospođama i gospodičnama prilagođen, poluobnažene ili potpuno obnažene nabrekle mladiće, nije poznato). Suvremenim feminističkim rječnikom rečeno, uvedena je erotska i pornografska rodna segregacija puljske punoljetne populacije koja nije zasmetala ni muškim ni ženskim konzumentima. Unatoč komercijalnom podilaženju, uglavnom mornaričkom (i proleterskom) gledateljstvu i (odvojeno) njihovim prijateljicama, kino Edison u baraci pokraj Tržnice nije izdržalo kvalitetniju kinodvoransku konkurenciju (i pristojniji filmski program) te se tiho gasi potkraj 1907.

Montažna daščara, provizorna baracca, dom (kinodvorana) prvoga stalnoga kina Internazionale i kasnijega Edisona u Puli, ubrzo je srušena za nova gradska zdanja, tako da je materijalni trag prvoga puljskoga kinematografa (ni fotografija nije pronađena) nestao u gradbenim mijenama, u urbanoj prošlosti Pule, što je za puljsku bremenitu i vremešnu povijest posve normalna i nimalo neočekivana pojava.

\section{Prešućena Pula}

Prema do sada poznatim relevantnim izvorima, Pula je drugi grad na prostoru današnje Hrvatske sa stalnim kinematografom (kino Internazionale), a vrlo je brzo za njim otvoren treći (kino Excelsior) te četvrti (drugo kino Edison) stalni kinematograf. Nešto ranije, sedam tjedana prije puljskoga kina Internazionale (i 12 dana prije [polu]stalnoga prvoga kinematografa Edison), 13. travnja 1906. otvoren je prvi stalni hrvatski kinematograf u Rijeci, Salone Edison u prizemlju kuće Adamić na Fiumari 2 (danas Fiumara

154 Palinić, „O povijesti riječkih kinematografa - prvi stalni kinematografi: Salone Edison, Elektra, Progresso“, 97-1 10; ista, „O povijesti riječkih kinematografa: Cinematografo Olimpo, Margherita, Urania, Armonia“", 59-68.

155 Škrabalo, 101 godina filma u Hrvatskoj, 26.

156 „Cinematografo Edison, chioschi Priora, vicino al Mercato. Questa sera dalle 6 alle 9 serata nera, per solo signore.“, „Cinematografo Edison“, Il Giornaletto di Pola, 21. ožujka 1907. 
14) ${ }^{157}$, a Zagreb s Pathé bioskopom („električnim kazalištem“, kako u najavi stoji), kasnije preimenovanim u kino Union, u Gajevoj 1, to čini tek negdje u studenome (nepoznata datuma) iste godine. No, jedina povijest kinematografije u Hrvata, 101 godina filma u Hrvatskoj, 1896.-1997., bilježi: „Iste godine kad i Zagreb (1906.) dobivaju svoj prvi kino Pula i Rijeka; Split, Zadar, Sušak 1907., dakle svega godinu dana kasnije, a Dubrovnik 1908. godine. ${ }^{“ 158}$ Uz epski opis prvoga zagrebačkog kina, ${ }^{159}$ publicist Ivo Škrabalo izostavlja pravi redoslijed pojavljivanja stalnih kinematografa u Hrvatskoj, zaboravlja zapisati datume Rijeke i Pule, gdje su do tada (dakle, studeni 1906.) već otvorena četiri stalna kinematografa, prvo u Rijeci (Salone Edison) i potom tri u Puli (kina Internazionale, Excelsior i Edison), samo kako bi Zagreb iskočio u prvi plan. ${ }^{160}$

Škrabalova prešućivanja (zanemarivanja) povijesnih, svima dostupnih podataka potom su, kao izvor iz pera renomirana povjesnika hrvatske kinematografije i autora od povjerenja, takva nepotpuna i pogrešna ušla kao vjerodostojna (i još uvijek ulaze) u enciklopedije: „Prve projekcije većinom se izvode u prostorijama s drugom namjenom, a prvi stalni kinematograf otvara se 1906. u Zagrebu; slijede dvorane u Puli (iste godine), te 1907. i u Dubrovniku, Splitu, Sušaku, Rijeci i Zadru, pa se sredina prvog desetljeća smatra razdobljem početka kinofikacije Hrvatske.“, ${ }^{161}$ „Filmski programi, od reda uvezeni, isprva su se prikazivali u dvoranama s drugom namjenom;

157 Palinić, „O povijesti riječkih kinematografa - prvi stalni kinematografi: Salone Edison, Elektra, Progresso“, 97-110.

158 Škrabalo, 101 godina filma u Hrvatskoj, 32.

159 „U predvorje, ukrašeno s nekoliko velikih zrcala što su imala dočarati raskoš, od vremena do vremena dopirao bi cilik konjskoga tramvaja koji je s obližnje postaje polazio na put nepopločanom Ilicom. Na ulazu dvorišne zgrade u Gajevoj ulici broj 1, preko puta sumornog zdanja Bolnice milosrdne braće, tiskalo se svakoga popodneva i večeri poprilično mnoštvo. Glasosvirač Mahalup već bi preludirao na pijanu ispred zastora, a posjetitelji su se uz nekoliko stuba penjali u amfiteatralnu dvoranu da bi se tamo, sukladno svom staleškom položaju i plaćenoj cijeni ulaznice, razilazili u vidljivo odijeljene prostore koji su nosili naziv prvo, drugo i treće mjesto." Isto, 26.

160 Premda Škrabalo u svojoj knjizi 101 godina filma u Hrvatskoj iz 1998. (koja je proširena, nadopunjena i izmijenjena verzija prethodne, jugoslavenskome samoupravnom socijalizmu dijelom nepodobne knjige Ivo Škrabalo, Između publike i države: povijest hrvatske kinematografije 1896-1980., Zagreb 1984.) napominje da se „ne odriče ambicije da čitatelja upozna s točnim i provjerenim činjenicama (onoliko koliko su do sada poznate)“ te da je u njoj „opsežna bibliografija knjiga, časopisa i članaka iz kojih je autor crpio podatke za svoje izlaganje, tako da se uz malo truda gotovo svaka činjenica može provjeriti“ (13), on to provjereno ne čini, već koristi zastarjele, odavno nerelevantne i prevladane podatke (ali zagrebocentičnom Škrabalu prihvatljive). U konkretnom slučaju drži se Kosanovićeve pretpostavke iz 1985.: „Godine 1906. započinje u Hrvatskoj otvaranje prvih stalnih kina - otprilike u isto vrijeme kada se takav novi tip kina otvarao i u drugim europskim zemljama. Prvo stalno kino na teritoriji Hrvatske bilo je vjerojatno kino Union u Zagrebu, otvoreno na početku Gajeve ulice (otprilike na mjestu gdje se danas nalazi zgrada hotela Dubrovnik." (Kosanović, Počeci kinematografije na tlu Jugoslavije 1896-1918, 139), pretpostavke koja je odavno napuštena novim istraživanjima samoga Kosanovića i drugih istraživača.

161 Ante Peterlić, „Jugoslavija, Hrvatska“, u: Ante Peterlić (gl. ur.), Filmska enciklopedija, sv. 1 (A-K), Zagreb 1986., 633. 
prva stalna dvorana otvorena je 1906. u Zagrebu, a zatim iste godine u Puli, pa 1907. u Dubrovniku, Splitu, Rijeci, na Sušaku i u Zadru."162 te stručne i znanstvene knjige: „Prvi stalni kinematograf otvoren je u Pittsburghu 1905., u Zagrebu samo s jednom godinom, a u Splitu, Zadru, Sušaku i Rijeci - s dvije godine zakašnjenja.“, ${ }^{163}$ „Prvo stalno kino u Hrvatskoj, Pathé bioskop ('električno kazalište'), otvoreno je u studenome 1906. u Gajevoj ulici br. $1 \mathrm{u}$ Zagrebu, godinu dana prije uvođenja električne struje u cijelom gradu; iste godine otvorena su stalna kina i u Puli te Rijeci, a iduće godine i u drugim gradovima pa se kratka dominacija putujućih komercijalnih prikazivača filmova približila svome kraju. “164 I tako redom koje se god filmske, povijesne, enciklopedijske ili publicističke publikacije dotaknemo nailazimo na nepouzdane (pogrešne) podatke početaka hrvatske kinofikacije, otvaranja prvih kinematografa u Hrvatskoj.

Ponovimo, prema postojećim vrelima: prvo stalno kino u Hrvatskoj je Salone Edison u Rijeci (13. travnja 1906.), drugo je stalno kino Internazionale u Puli (3. lipnja 1906.), treće je kino Excelsior u Puli (početak srpnja 1906.), četvrto je kino Edison u Puli (6. listopada 1906.) i tek peto u Hrvatskoj je Pathé bioskop u Zagrebu (studeni 1906.). ${ }^{165}$

„Upravo u vrijeme kada se u hrvatskim gradovima otvaraju prvi stalni kinematografi (najranije u Rijeci i u Zagrebu), dolazi u nas do zaostajanja u razvoju kinematografije koji smo do tada koliko-toliko ažurno pratili.“166 Do zaostajanja kinofikacije dolazi u Zagrebu, što Škrabalo pojednostavljeno generalizira za čitavu Hrvatsku (,u nas“), ali takva neažurna zagrebačka situacija kinofikacije nije bila u Puli (s otvorena dva polustalna i dva stalna, ili četiri stalna kinematografa samo u 1906.) ni u Rijeci. Samo su Rijeka i Pula na području današnje Hrvatske prednjačile u kinoprikazivačkoj djelatnosti prvoga desetljeća dvadesetoga stoljeća prateći europska (i svjetska) kinematografska kretanja.

\footnotetext{
162 „Hrvati, film“, u: August Kovačec (gl. ur.), Hrvatska enciklopedija, sv. 4 (Fr-Ht), Zagreb 2002., 701; http:// www.enciklopedija.hr/Natuknica.aspx? ID=26386.

163 Laura Šakaja, Kultura i prostor: prostorna organizacija kulturnih djelatnosti u Hrvatskoj, Zagreb 1999., 96. 164 Nikica Gilić, „Filmski medij“, u: Zrinjka Peruško (ur.), Uvod u medije, Zagreb 2011., 92.

165 Ako bismo i dva prva puljska kinematografa uvrstili u kategoriju polustalnih kina (Sala Edison i kino Internazionale), kao što smo dvojako i skeptično gore opisali, tada svejedno na drugu poziciju dolazi puljsko kino Excelsior, za koje zasigurno nema nikakve nedoumice u kategorizaciji stalnoga kinematografa. 166 Škrabalo, 101 godina filma u Hrvatskoj, 31.
} 


\section{Kino Internazionale (1907. - 1911.)}

Pred sam Božić, 21. prosinca 1907., otvoreno je još jedno kino u Ulici Sergijevaca (zgrada bivše Narodne tehnike s dugom tradicijom kinematografske i filmske djelatnosti; u njoj je stolovala za socijalističkih vremena direkcija Međuklupskoga i autorskoga festivala amaterskog filma, a ondje je bilo i sjedište Kino kluba Jelen): „Novo veliko kino Internazionale gospodina Bernardisa, u Ulici Sergijevaca 77, započelo je sinoć s predstavama i nastavlja danas u 2 sata poslijepodne. ${ }^{{ }_{167}}$ Nimalo originalna naziva, dapače (poput Edisona) zbunjujućega za praćenje kinofikacije grada, kino Internazionale (kao prvo, prije samo godinu i pol, Ivana Tominca) u puku se češće nazivalo kino Bernardis ili kino Leopoldo (što mu postaje narcisoidni službeni naziv od kolovoza 1911.), prema vlasniku Leopoldu Bernardisu, puljskome ugostitelju, vlasniku Restorana Leopold u istoj zgradi. ${ }^{168}$

Koliko je veliko i što je za ono vrijeme značila sintagma „veliko kino“ govori podatak da su tada kina sa stotinjak (do dvjestotinjak) običnih (kućnih) drvenih, nenumeriranih i nepričvršćenih stolica, odijeljenih niskim ogradama ili prolazima (za bolje, srednje i lošije gledateljske pozicije u sali), s kinoprojektorom bez kabine i nasuprot nategnutim platnom (plahtom s crnim okvirom) na zidu, već smatrana velikim kinom. Važniji je položaj (od relativne veličine) kinematografa Internazionale (kina Bernardis) u samom središtu grada na koncu Ulice Sergijevaca (na uglu s Usponom Franje Glavinića), u blizini Slavoluka Sergijevaca (i tada kina Excelsior), mjesta u gradu koje će punih četrdeset godina mijenjati (nazive) kina i nastaviti s filmskim organizacijama i kino klubom do konca dvadesetoga stoljeća (tu je za fašizma bilo popularno derutno kino Savoia, u puljske mularije zvano cine Pistola, a za socijalizma Kino klub Jelen i direkcija Međuklupskoga i autorskoga festivala amaterskog filma, Male Pule, festivala jugoslavenskoga amaterskog filma).

Kinematograf Bernardis, u sklopu kavane (restorana) Leopold, kao dopunska zarada vlasnika kojemu je glavna djelatnost ipak bila ugostiteljstvo nije bilo reprezentativno, prije prosječno i neugledno kino, u neku ruku dodatna zabava stalnih gostiju kavane i slučajnih posjetitelja. Program (neredovitoga oglašavanja u tisku) je bio uobičajena i ondašnjega standar-

167 „Cinematografo Internazionale“, Il Giornaletto di Pola, 22. prosinca 1907.

168 „Leopold Bernardis, ugostitelj iz Pule, vlasnik jednog od prvih stalnih kinematografa u Puli, otvorenog 1907. pod nazivom Internazionale (kasnije popularno nazvan Bernardis ili Leopold, što mu je od 1911. i službeni naziv.“ Kosanović, Leksikon pionira filma, 28. 
dnog sadržaja (što se trenutno nalazilo na komercijalnom tržištu filmova), većinom komedija, dokumentaraca, ljubavnih i erotskih (vjerojatno i „,crnih večeri“ koje nisu oglašavane u novinama i privatnih projekcija) drama za široke mase, ${ }^{169}$ mahom radničku i nižu malograđansku publiku Pule.

Reproduktivna kinematografija bila je (i uglavnom ostala) privilegij žitelja grada, masovna urbana zabava (malo)građana, samo vikendom i praznikom u kino su zalazili i radnici s periferije i predgrađa i pokoji znatiželjan seljak iz obližnjih puljskih sela i zaseoka. „Kad bi se navečer mornari povukli na brodove, radnici na periferiju i u sela (trebalo je rano ustajati), grad bi se naglo smirio. Večernje priredbe u kazalištu, mornaričkom kasinu i novim kinematografima posjećivali su oficiri i mornarički činovnici, državni namještenici i đaci, školovani ljudi i poneki trgovac. Tramvaj je svake večeri radio do posljednje kazališne ili kinematografske predstave i sačekivao posjetnike da ih poslije predstave odveze kućama.“170

\section{Kino Edison (1908. - 1915.)}

Talijanska braća Fragiacomo (svježi puljski doseljenici o kojima se, što nije teško pogoditi, malo toga zna, a najviše se toga ne zna, kao recimo koliko ih je uopće bilo ili njihova imena) ${ }^{171}$ odlučuju u vojnoj Puli prikazivati premijerne i najnovije filmove, mahom talijanske proizvodnje i bečke distribucije, u novouređenoj kinodvorani, u arteriji grada, posred Ulice Sergijevaca (Via Sergia 34, danas približno na mjestu ili u blizini Saveza kulturno-umjetničkih društava grada Pule). Puljani od 17. svibnja 1908. ${ }^{172}$ imaju novo kino, a kako već dugo nema u gradu novoga imena kina, braća Fragiacomo (očito „puni inspiracija“) odlučuju se za tada „rijetki“ naziv kino Edison (nedavno ugasloga kinematografa kraj Tržnice i onoga još ranije na Portarati). Otvaranje kina skromno je najavljeno 16. svibnja: „Večeras se otvara novo kino Edison u Ulici Sergijevaca 34, pokraj staroga kazališta Ciscutti“"173 (prijaš-

169 Primjerice: „U ulici Sergia broj 77, restauracija Leopold, od 5. t. mj. do 8 marča imade jako zanimljiv sliedeći program: Gospoda se spremaju na šetnju (komično), Sa gondolom u Mletcima (iz naravi), Put oko zviezde repatice (fantastično), Nemogući razvod (dramatično), Zadnja vještica (u 6 slika).“, „Kinematograf International“, Omnibus, 6. ožujka 1908.

170 Mate Balota, Puna je Pula, Zagreb 1960., 103.

171 „Braća Fragiacomo, drugi podaci nepoznati. Lipnja 1908. otvorili su peti po redu stalni kinematograf u Puli, Edison u Ulici Sergia, koji je radio do 1915. Također su organizirali i Kinematografsko poduzeće Fragiacomo i Nicolini koje je u kinu Edison prikazivalo svoje originalne filmove. Njima se može pripisati film Veliki zbor vatrogasaca u Puli, prikazan studenoga 1909." Kosanović, Leksikon pionira filma, 73.

172 Kosanović u Kinematografskim delatnostima u Puli, 50, navodi pogrešan, kasniji datum (13. lipnja 1908.) za početak rada ovoga kinematografa.

173 „Un nuovo cinematografo“, Il Giornaletto di Pola, 16. svibnja 1908. 
njega kazališta Teatro Nuovo uz crkvu Gospe od Milosrđa), a sutradan je uslijedila isprika: „Otvaranje novoga kina umjesto jučer, kako je bilo najavljeno, održat će se danas. "174 Kako je šlampavo krenulo, tako je i nastavljeno: kinodvorana Edison se zaista uspjela (valjda svečano?) otvoriti 17. svibnja, ali samo dvorana jer posjetitelji nisu mogli gledati filmove zbog nenadanoga kvara na kinoprojektoru. ${ }^{175}$ Gledanje filmova omogućeno im je, s onim već kupljenim ulaznicama, tek četiri dana kasnije, 21. svibnja $1908 .{ }^{176}$

Unatoč nesretnom početku, uskoro su se fratelli Fragiacomo kvalitetno iskupili recentnim repertoarom premijernih filmova koji su netom prije imali europsku (svjetsku) pretpremijeru u Parizu, Beču, Berlinu, Budimpešti, Milanu, Trstu, a u puljskome su kinu Edison projicirani svega dva-tri tjedna kasnije. Tako je 20. rujna 1908. na programu, dva tjedna poslije Trsta, igrana rekonstrukcija zločina Ubojica pjevačice Lucienne Fabry (Lo squartatore della canzonettista Lucienne Fabry) ${ }^{177}$ Salvatorea Spine, „izvrstan i uspješni kinematografski snimak u boji, duljine 320 metara"178; talijanski dokumentarac Porinuće bojnoga broda Erzherzog Franz Ferdinand u brodogradilištu San Marco kraj Trsta snimljen je 30. rujna, a u Puli je prikazan već 11. listopada $1908 .{ }^{179}$; u povijesti filma prekretnički značajno djelo Ubojstvo vojvode od Guisea (L'Assassinat du duc de Guise) ${ }^{180}$ imalo je premijeru u Parizu 17. studenoga 1908., a u kinu Edison projicirano je tri tjedna kasnije, 6. prosinca $1908 .^{181}$; prikazuju se i medicinski dokumentarni filmovi, šest krvavih kirurgijskih operacija doktora Doyena ${ }^{182}$, snimke „samo za odrasle“ (a nisu pikantne, ni tolerantne) koje su malobrojni gledatelji uspjeli odgledati do kraja... Braća Fragiacomo prvi su uveli u Puli, od travnja 1910., ${ }^{183}$ redovito

\footnotetext{
174 „Cinematografo Edison“, isto, 17. svibnja 1908.

175 „Cinematografo Edison“, isto, 18. svibnja 1908.

176 „Evo novoga programa koji će se prikazati od 21. do 24. ovoga mjeseca: U carstvu igračaka ili dječji san; Žrtva (senzacionalni prizor u 9 slika); Živi pijesak planine San Michele (emotivna drama u 5 dijelova); Majmun zubar (komično).“, „Cinematografo Edison“, isto, 21. svibnja 1908.

177 Kosanović, Trieste al cinema, 115.

178 „Kinematograf Edison“, Polaer Tagblatt, 20. rujna 1908.

179 „Kinematograf Edison“, isto, 11. listopada 1908.

180 „Zapravo, od sama početka nastojanja da se film prihvati kao umjetnost u visokoobrazovnoj sredini to se ostvarivalo u pokušajima da se filmovi uključe u razred drama preuzimanjem paradigmatskih (simptomatskih) osobina kazališno cijenjenih drama. Prvi deklarirani 'umjetnički filmovi' filmskoga poduzeća Film d'art (npr. Ubojstvo vojvode od Guisea / L'Assassinat du Duc de Guise, Francuska, 1908, Charles Le Bargi i Albert Lambert) snimani su kao izravno nadovezivanje na najuglednije predloške kazališne drame." Hrvoje Turković, Film: zabava, žanr, stil: rasprave, Zagreb 2005., 209.

181 „Kinematograf Edison“, Polaer Tagblatt, 6. prosinca 1908.

182 „Cinematografo Edison: Operazioni chirurgiche“, Il Giornaletto di Pola, 13. rujna 1910.

183 „Salone Edison“, Il Giornaletto di Pola, 9. travnja 1910.
} 
prikazivanje filmskih žurnala (Pathé Journal), što je kasnije postala redovita praksa i drugih kina.

Kino Edison braće Fragiacomo pratilo je u stopu novi talijanski i europski filmski repertoar te ga promptno dovodilo u Pulu mijenjajući program gotovo svakodnevno (s tematskim večerima: utorkom navečer drama i petkom komedija). Dok su ostala dva stalna kina (Internazionale i Minerva) uglavnom s mješovitim programom, ponajviše repriznih i nešto manje premijernih komercijalnih filmova, kino Edison je ekskluzivni premijerni kinematograf, s probranim i kvalitetnim izborom tadašnjih umjetničkih i dokumentarnih filmova, koji je skrbio o unutrašnjem uređenju (redovito je obnavljan) i izgledu (u tisku je nazivan kinematografskim salonom) te $\mathrm{u}$ nj zalaze viši društveni slojevi. Tih godina slovi za „prvi kinematografski salon u Puli, Ulica Sergijevaca 34, najudobniji i najelegantniji kinematograf u Puli“184. Pred Prvi svjetski rat pomalo gubi reputaciju i primat u gradu, a kada su talijanska braća uvidjela ratni obrat, početkom 1915. zatvaraju kino.

Sredinom 1908., nakon što se u samo dvije godine izredalo šest polustalnih i stalnih kinematografa različitoga uspjeha i trajanja, u gradu su ostale djelatne tri kinodvorane: „Trenutno u Puli rade tri kina: Théâtre Pathé Frères u Politeami Ciscutti, kino Internazionale gospodina Leopolda Bernardisa i kino Edison u Ulici Sergijevaca u blizini Bogorodičine crkve. Prvi stalni kinematograf gospodina Covinija zatvoren je već nekoliko dana jer ga je nadvladala konkurencija. “185 Nepotpisani novinar (kao svi i prošli i današnji) zaboravio je spomenuti prvi Internazionale i dva prethodna Edisona (Curielov na Portarati i u Bezimenoj uličici poslije prvoga kina Internazionale), a putujući kinematograf Théâtre Pathé Frères već se toliko puta pojavljuje u Puli (udomaćio se svakih nekoliko mjeseci u Ciscuttiju) da ga (novinarski nepromišljeno) smatra stalnim gradskim kinom.

\section{Kino Minerva (1908. - 1915.)}

Vlasnik najuglednije i filmskoj projekciji najprimjerenije dvorane u Puli, gospodin Covini, pritisnut financijskim nedaćama (i okolnom konkurencijom) polovicom srpnja 1908. prodaje svoj kinematograf Excelsior na Portarati izvjesnoj gospođi Benussi (o kojoj se, naravno, malo toga zna), koja ga ponovno nakratko otvara krajem kolovoza iste godine (posljednji se

184 „Primario salone cinematografico“, La Fiamma, 29. travnja 1911. 
put pojavljuje oglas u novinama za kino Excelsior 22. listopada). Nedugo potom, već 31. listopada 1908. promijenjen mu je naziv (budući da su bila već „zauzeta“ imena Edison i Internazionale) u kino Minerva ${ }^{186}$, kada ga od Benussijeve (možda supruge suvlasnika Kavane Specchi ${ }^{187}$ nasuprot Arsenala) otkupljuje (skuplje ili jeftinije?), po svemu sudeći jer se javlja kao kasniji vlasnik, (opet) puljski ugostitelj Karlo Matelić (Matelich) ${ }^{188}$, negdanji vlasnik poznate kavane Commercio ${ }^{189}$ na trgu Slavoluka Sergijevaca. Kasnije i Matelić, umoran od nepoznate mu kinematografije, najvjerojatnije početkom drugoga desetljeća prodaje kino Minerva izvjesnom Giovanniju Valentichu (Ivanu Valentiću). ${ }^{190}$ Kino Minerva poput nedalekoga kinematografa Internazionale ima na programu (mijenja ga svaka dva-tri dana) većinom standardni konfekcijski filmski materijal, no ipak s više premijernih komercijalnih naslova pionirskih igranih filmova.

Pula je kao drugi grad u Europi (i prvi u Hrvatskoj), odmah poslije Beča, imala prigodu upravo u kinu Minerva 13. studenoga 1913. upoznati kinetofon (kinetophone), cinematografo parlante, „govoreći kinematograf“, ${ }^{191}$ Edisonov uređaj koji omogućuje reprodukciju zvuka na filmu i koji će, kako se reklamirao, „za budućnost sačuvati lik i glas ljudi“. „Edison je razvijao zvučni sustav kinetophone s mehaničkim zapisom zvuka. Patent na snimanje i reprodukciju zvučnog filma pojavio se 8 . veljače 1908., a dobio ga je 16. svibnja 1916. Sam je sustav uveden 1913., ali je napušten 1915. godine. Snimljeno je 19 filmova kod kojih je zvuk bio pohranjen na celuloidnom cilindru promjera $14 \mathrm{~cm}(5,5$ inča). Projektor je bio povezan s fonografom, koji se nalazio na drugom dijelu dvorane. Sustav, za koji je izgrađen i filmski studio za snimanje zvučnih filmova napušten je, među ostalim, zbog sindikalnih problema, i neobučenosti projekcionista, nemogućnosti uspostave sinkroniteta pri pucanju filma, problema oko patentnih prava. “192 Prikazano je pet ozvučenih filmova.

Kino Minerva Giovannija Valenticha prestaje s radom krajem prve godine Velikoga rata, travnja ili svibnja 1915. (ulaskom Italije u rat na strani

186 „Cinematografo Minerva“, Il Giornaletto di Pola, 1. studenoga 1908.

187 Dobrić, „Stare pulske kavane“, 43.

188 „Karlo Matelić, ugostitelj iz Pule. Od jeseni 1908. vlasnik kinematografa Minerva (koji je prethodne dvije godine radio pod nazivom Excelsior) i koji je prikazivao filmove sve do 1915. “ Kosanović, Leksikon pionira filma, 140 .

189 Dobrić, „Stare pulske kavane“, 43.

190 „Comunicato“, Il Giornaletto di Pola, 18. rujna 1913.

191 „Cinema Minerva“, isto, 13. i 15. studenoga 1913.

192 Midžić, Živuće fotografije i pokretne slike, 175. 
Antante, protiv Austrije), renovira se početkom 1916. i otvara pod novim nazivom kino Novara, da bi ponovno, za talijanske okupacije, krajem 1918. postalo kino Minerva.

\section{Kino Leopoldo (1911. - 1918.)}

U kolovozu 1911. (Pula tada već broji više od 60 tisuća žitelja) kino Internazionale (ondašnja Via Sergia 77), koje se najčešće u tisku još ranije nazivalo, prema ugostiteljskome vlasniku, i kino Bernardis i kino Leopoldo, službeno postaje kino Leopoldo (u Il Giornalettu) ili kino Leopold (u Tagblattu). U oglašavanju, reklamiranju repertoara po novinama, kino Leopoldo prvo je uvelo novinu ožujka 1912., kada je pored naziva filma Dama s kamelijama navelo i ime glumice Sarah Bernhardt, ${ }^{193}$ što je nagovještaj stelarizacije kinematografije, buduće posvemašnje popularizacije filmskih glumica i glumaca, pojave filmskih zvijezda. Kino Leopoldo od početka 1914. povremeno ne radi ili je otvoreno samo vikendom i takvim (ne)radnim tempom ostaje otvoreno i zatvoreno do kraja Prvoga svjetskoga rata.

„Uspoređujući s drugim gradovima, nailazimo na zapanjujuće podatke: u Rijeci je do kraja 1911. otvoreno čak devet kinematografa, a u znatno većem Zagrebu svega dva (Union i Kinematograf ćirilo-metodskih zidara, otvoren 1907.). Zanimljiv je, također, primjer Pule u kojoj su do 1912. otvorena četiri kinematografa (Internacional, Excelsior, Internacional (novi), Edison). ${ }^{194}$ Istine radi, te 1911. godine u Puli djeluju samo tri kinematografa: Minerva, Edison i Leopoldo (iduće se godine, 1912., otvara četvrti kinematograf, kino Ideal), dok ih je ukupno bilo, do navedene 1911., otvoreno sedam, od kojih su tri promijenila prijašnje nazive (novi vlasnici, nova imena) i jedan se ugasio, prvi puljski stalni kinematograf Internazionale u paviljonu na Tržnici, kasniji Edison, ${ }^{195}$ a u dobrano, zapravo europski kinoficiranoj Rijeci

\footnotetext{
193 „Kinematograf Leopold“, Polaer Tagblatt, 19. ožujka 1912.

194 Palinić, „O povijesti riječkih kinematografa - prvi stalni kinematografi: Salone Edison, Elektra, Progresso“, 98, bilj. 8.

195 Puljska usmena povijest, gradska usmena predaja, nepregledan izvor pretjerivanja i svakojakih neumjerenosti, stvara urbane legende i bajke, zanimljive i maštovite laži koje su u bližoj prošlosti vrlo brzo postajale neupitne i nepobitne činjenice. Tako je bilo i u prebrojavanju negdašnjih kina; bilo ih je uvijek koliko se komu svidjelo. Mitomaniju je započeo kinoizvikivač Nino Giorgesi izjavom da je početkom drugoga desetljeća 20. stoljeća u Puli, „u jednom periodu bilo čak 11 kinematografa, od kojih pet u Prvomajskoj ulici.“ Čehić, „Nino Giorgesi: filmski kroničar Pule“, 79. Legende ne bi bile legende (u svemu pretjerane, napuhane fantastične priče) kada se s vremenom ne bi još više preuveličavale i predajom maštovito dotjerivale do neslućenih razmjera (visina). Nakon četrdesetak godina Giorgesijeva pretjerivanja, novinar Zoran Angeleski novinarski nonšalantno ponovno prebrojava austrijska puljska kina, kada je „egzistiralo više od deset, u jednom trenutku, kažu upućeniji, 14 kina istodobno“. Zoran Angeleski, „Kino Istra: Shizo u vrtlogu svesti“, u: Boris Bogunović (ur.), Pulski đir: mjesta memorije grada, Pula 2012., 96. Nikada, baš nikada, u Puli nisu istovremeno bile, ni u kom razdoblju kinofikacije grada, filmske projekcije ni u 11 ni u 14 kina.
} 
tada su: Salone Edison (1906.), Kinematografička dvorana Elektra (1907.), Cinematografo Olimpo (1907.), Grande cinematografo Parigi (1908.), Cinematografo Progresso (1909.), Nuovo cinema Plasse (1910.), Cinematografo Centrale (1909.), kino Sušak (1910.) i Cinema-teatar Argentina (1911.). ${ }^{196}$

U mnogo većem Trstu te 1911. godine prikazuju se filmovi u 18 kina, a do tada ih je ukupno bilo otvoreno 26. ${ }^{197}$ Pored brojnih kina, Rijeka se izdvaja i u praćenju filmskih programa: Grande cinematografo Parigi već 1910. pokreće, svaka tri-četiri dana, vlastito glasilo Cinema giornale di Parigi (uređivao ga je Camilo Fiorello, ${ }^{198}$ tiskao Emidio Mohovich), što je prva zabilježena filmska revija (kino-novine) tiskana u Hrvatskoj. „Novine su tiskane na dva lista $(42 \mathrm{~cm})$ bez oznake godišta, bez paginacije i bez slika. Sadržaj je bio ujednačen, te je u svim sačuvanim primjercima na prvoj stranici najava novog filma, na drugoj stranici pripovijetka (ili filmska novela $\mathrm{u}$ nastavcima), poneka pjesma i humor, a na trećoj i četvrtoj stranici objavljivane su reklame i oglasi riječkih gospodarstvenika."199

\section{Kino Ideal (1912. - 1937.)}

Na sjevernoj strani Giardina (Korza), gdje se danas nalazi zgrada Financijske agencije (FINA), prije Zavoda za platni promet (ZAP), još prije Službe društvenog knjigovodstva (SDK), i prije nego što je sagrađena Banca d'Italia za fašizma, od 15. se rujna 1912. nalazilo kino Ideal, ${ }^{200}$ te godine četvrto stalno kino u gradu. Svečano je otvoreno ondašnjim cjelovečernjim koloriranim igranim (danas bismo to nazvali srednjometražnim) filmom Zavjera protiv generala Murata (Una congiura contro Murat, 665 metara, 30-ak minuta), komedijom Andréa Deeda Cretinetti $i$ Brazilčeve čizme (Cretinetti e gli stivali del Brasilero) $)^{201}$ i nekoliko kraćih filmova. Vlasnik kina Ideal bio je mehaničar i instalater elektrorasvjete iz Pule Nicolò Martin, ${ }^{202}$ koji je još svibnja davne

\footnotetext{
196 Igor Žic, Riječka gostoljubivost: hoteli, restorani, gostionice, kavane, kupališta, Rijeka 2000., 50.

197 Kosanović, Trieste al cinema, 259-262.

198 „Camilo Fiorello, iz Rijeke. Urednik lista Novine kinematografa Pariz (Giornale cinema Parigı) koji je izlazio u Rijeci od 1910. do 1914. kao glasilo kinematografa Parigi. Bilo je to najstarije glasilo koje je izdano na tlu jugoslavenskih zemalja. Ukupno je objavljeno blizu 400 brojeva, od kojih je samo nekoliko sačuvano. Pored podataka o promjenama repertoara u listu su objavljivani različiti članci o filmu i drugim zbivanjma.“ Kosanović, Leksikon pionira filma, 70.

199 Vjekoslav Majcen, Hrvatski filmski tisak do 1945. godine, Zagreb 1998., 58.

200 „L'apertura dal nuovo cinematografo Ideal“, Il Giornaletto di Pola, 15. rujna 1912.

201 „Kinematograf Ideal, Viale Carrara“, Polaer Tagblatt, 15. rujna 1912.

202 „Nicolo Martin, mehaničar i elektroinstalater iz Pule. U Trstu 1908. položio je ispit za kinooperatera, radio je u kinematografu Nicolini u Puli, da bi 1912. otvorio svoj stalni kinematograf Ideal koji je radio do 1918.“ Kosanović, Leksikon pionira filma, 139.
} 
1908. u Trstu, otkad je Pokrajinsko namjesništvo za Primorje (Küstenländische Statthalterei) nametnulo obvezu posjedovanja dozvole za prikazivanje filmova, među prvima položio tečaj (stručni ispit) za kinooperatora i zasigurno je neko vrijeme radio („u fušu“) u nekom od putujućih ili puljskih kinematografa prije otvaranja vlastitoga kina.

Novo kino standardnih uvjeta i primjerena uređenja pratilo je premijernu europsku kinematografiju. Tako istovremeno u Puli, u kinu Edison (prvi dio) i Ideal (drugi dio) 12. rujna 1913. (kao svjetska distribucija blockbustera stoljeće kasnije, samo dvadeset dana poslije službene talijanske distribucije 24. kolovoza) započinju s premijernim prikazivanjem (u dva dijela i dva kina) talijanske uspješnice, integralnoga cjelovečernjega igranog filma Marija Caserinija i Eleuterija Rodolfija Posljednji dani Pompeja (Gli ultimi giorni di Pompei, prema nekim povjesničarima filma i filmolozima prvi cjelovečernji povijesni igrani film), spektakla „kojega prikazivanje traje više od tri sata" ${ }^{203}$, duljine 3.500 metara $^{204}$ (vjerojatno promidžbeno pretjerivanje ili je ipak riječ o duljoj verziji dvodijelna filma; standardna duljina filma je 88 minuta ili 2.209 metara). I kino Minerva se pridružuje Edisonu i Idealu, istoga dana na istoj promidžbenoj stranici Il Giornaletta (3/4 stranice pripada kinima Ideal i Edison, a 1/4 Minervi) najavljuje „pravu, istinsku verziju“ pompejske tragedije Jona ili posljednji dani Pompeja (Jone ovvero Gli ultimi giorni di Pompei) ${ }^{205}$ Ubalda Marije Del Collea i Giovannija Enrica Vidalija (2.500 metara, oko 95 minuta), u svakoj mjeri daleko lošije kinematografsko ostvarenje. Dakle, od četiri stalna kina u gradu, tri prikazuju tematski jednake (pompejske) filmove pa se razvila polemika (kino Ideal napao je i optužio Minervu, a ova mu je uzvratila...) u Il Giornalettu. ${ }^{206}$

Početkom i u jeku Prvoga svjetskoga rata kino Ideal povremeno i neredovito radi, a početkom 1917. dobiva novoga vlasnika (nepoznatoga imena i prezimena) koji obećava „da će od sada unaprijed davati samo vrlo vrijedne i velike kinematografske predstave praćene uz fini orkestar." ${ }^{207} \mathrm{Uz}$ povremeno stalno kino u Politeami Ciscutti, kino Ideal jedino je kino koje i nakon Prvoga svjetskoga rata nastavlja prikazivati filmove pod istim imenom.

203 Sadoul, Povïest filmske umjetnosti, 91.

204 „Gli ultimi giorni di Pompei, cinematografi Edison e Ideal“, Il Giornaletto di Pola, 12. rujna 1913.

205 „Cinematografo Minerva: Jone ovvero Gli ultimi giorni di Pompei“, isto, 12. rujna 1913.

206 „Comunicato“, isto, 15., 18. i 20. rujna 1913.

207 „Kino Ideal“, Hrvatski list, 31. siječnja 1917. 


\section{Kino Eden (1913. - 1914.)}

Nije prošlo ni četiri mjeseca (točnije, 117 dana i noći) od otvorenja četvrtoga stalnog kinematografa u Puli, kina Ideal, a već je 12. siječnja 1913. otvoren i peti, gdje drugdje nego u kavani (restoranu) u najfrekventnijoj Ulici Sergijevaca (Via Sergia 16): „Danas će se otvoriti novo kino Eden u Ulici Sergijevaca, u bivšem prostoru Valerio.“208 Puljski ugostitelj Francesco Scala, ${ }^{209}$ vlasnik popularnoga Cafféa Aurora u istoj ulici, otvara još jednu, novu gradsku kavanu Eden na početku Via Sergie (zgrada više ne postoji, za što su se pobrinuli Saveznici koncem Drugoga svjetskog rata bezobzirnim bombardiranjem grada; kasnije je na tom mjestu, u ondašnjoj Prvomajskoj ulici, Zajednica osiguranja pa Croatia osiguranje, a danas kojekakve prodavaonice, butici) u čijem je sastavu i kino Eden, duljine dvadesetak i širine sedam metara (poput većine puljskih kinodvorana), sala za stotinjak i nešto malo više gledatelja, ali s odvojenom projekcijskom kabinom, što je već postao sigurnosni standard. ${ }^{210}$ Još jedno usputno kino novaca nezasitnoga ugostitelja kojemu je stalo do filma i kinematografije koliko do - te godine otkrivenih - Bohrovih postulata. Pohlepni i neumjereni malograđanin Francesco Scala (vlasnik nekolicine ugostiteljskih objekata) nije dugo izdržao stariju, renomiraniju i iskusniju konkurenciju pa zatvara kino (za godinu i pol dana) srpnja 1914., netom pred Prvi svjetski rat.

Od prvoga otvorenog (polu)stalnog kina Edison (25. travnja 1906.) do početka Prvoga svjetskoga rata (28. srpnja 1914.) u Puli je otvoreno, u samom središtu grada, deset stalnih kinematografa (posljednji je u tom razdoblju kino Eden, 12. siječnja 1913.) različitih kategorija, od građanskočasničkih elitnih do proletersko-vojničkih s erotsko-pornografskim programima (bitna karakteristika proleterskoga i vojnoga grada), od kojih je pak pred Veliki rat ostalo pet djelatnih: jedna i druga brojka zorno pokazuju i jasno dokazuju europski trend započete ubrzane kinofikacije većih gradova prihvaćanjem nove zabave koju je mornarička Pula (napose njezine bestidne elemente) srčano prigrlila i prisvojila.

\footnotetext{
208 „Un nuovo cinematografo“, Il Giornaletto di Pola, 12. siječnja 1913.

209 „Francesco Scala, ugostitelj iz Pule, vlasnik nekoliko ugostiteljskih objekata. Siječnja 1913. otvorio je kinematograf Eden koji je radio do 1914." Kosanović, Leksikon pionira filma, 197.

210 „Il cinematografo Eden“, Il Giornaletto di Pola, 15. siječnja 1913.
} 
S pet svakodnevno otvorenih kina (1914.) $)^{211}$ - dva premijerna (Edison i Ideal) i tri komercijalno mješovita reprizno-premijerna (Leopoldo, Minerva i Eden) s ondašnjim recentnim filmskim repertoarom, kako ozbiljnim spektaklima tako i nezahtjevnim slikopisima - te povremenim ozbiljnijim projiciranjima u kazalištu Ciscutti i na Brijunima ${ }^{212}$, ili rijetkim prikazivanjima jeftinih komedija i svakojakih filmića upitna sadržaja i kakvoće po kavanskim (i sajmišnim) salama u sklopu varijetea, kabarea i sličnih zabavišta, u godinama pred Veliki rat Pula je bila kinematografski (kinodvoranama) i filmski iznimno dobro pokriven grad koji je promptno pratio gotovo sve europske (i svjetske) filmske domete preko ažurne, kvalitetne i brze distribucije filmova iz Trsta i Beča.

Za isto razdoblje „brojka od četiri stalna kinematografa u Zagrebu svakako svjedoči o tome da je film osvojio publiku. Ali ona je ujedno svjedočanstvo o našem uočljivom zaostajanju u filmskom razvoju, koje je u tom času već toliko da će fatalno zakočiti suvremeno korištenje novim medijem izražavanja i odgoditi nastanak nacionalne filmske umjetnosti za mnogo godina. Usporedbe radi, može se navesti da je - $\mathrm{u}$ isto vrijeme kada su $u$ Zagrebu radila 4 kinematografa - Budimpešta, glavni grad Ugarske, s kojom je Hrvatska bila vezana Nagodbom, imala 1912. čak 92 kinematografa, a godinu dana kasnije već 114 stalnih kinematografskih dvorana!“" ${ }^{13}$ Bliža i prirodnija bila bi usporedba Zagreba s Rijekom, koja tada (krajem 1914.) ima čak dvanaest kinematografa (pored devet prije nabrojenih, još su

211 Attilio Krizmanić, arhitekt znanstvenih namjera, neosporni autoritet puljske tvrđavne arhitekture, oponašajući amaterskoga filmoljupca Nina Giorgesija, prikrpio je Puli još kina: „Godine 1913-1914. u Puli je bilo stalno otvoreno jedanaest kina (Edison, Leopold, Eden, Ideal, Minerva, Nicolini, Valentić, Toffoli te u kazalištu Ciscutti, Mornaričkom kasinu i dvorani Apollo), dakle jedna dvorana na približno 8.000 stanovnika.“ Attilio Krizmanić, „Prostorni razvitak austrijske Pule“, u: Elmo Cvek (ur.), Srđa Orbanić (prir.), Pula: tri tisućljeća mita i stvarnosti, Pula 2005., 170. Godine 1913. u Puli je pet spomenutih stalnih kinematografa, a šest krajem 1914., kada su otvorena još dva (Politeama Ciscutti i Mornarički klub), uz zatvoreno kino Eden; ostala su kina Krizmanićeva izmišljotina i nonsensi: Josef Nicolini bio je snimatelj i kinooperator koji kina nije imao, Ivan je Valentić, kako smo vidjeli, vlasnik kina Minerva (Krizmanićeva podvala ponavljanja istoga kina u dva navrata), dvorana Apollo ustvari je pomoćna, kabaretska ili plesna (zabavljačka) sala Cafféa Apollo (,,sala Inferiore Apollo, Via Tradonico“) u kojoj je iznimno rijetko (jednom u ožujku 1907.) gostovao neki putujući kinematograf, a Toffoli je kino iz Krizmanićeva imaginarija.

$212 \mathrm{Za}$ mondenu i dokonu aristokraciju na Brijunima, za buržuje kojima masovna filmska zabava, unatoč visokim umjetničkim i estetskim ukusima, nije bila omražena, otvoreno je tri puta tjedno (srijedom, petkom i nedjeljom) kino-kazalište. „Vođeni željom da zabavni dio programa u ljetovalištu bude što sadržajniji ponudili smo našim dragim gostima, naročito za kišnih dana, počevši od 26. srpnja 1913., poseban program kinematografskih predstava u kinodvorani hotela Neptun III. Ugodna i prikladna kinodvorana ima 137 sjedećih mjesta s četiri izlaza u hodnik i dvoranu hotela. Prvorazredan i najsuvremeniji projektor Ernemann radi gotovo nečujno i projicira živuće slike iznimne oštrine na kinematografskom zaslonu. (...) Najnovije, tek snimljene filmove i dokumentarne snimke 'Pathé frères', 'Nordisk', 'Eclair' i drugih poznatih kompanija posjetitelji kino-kazališta na Brijunima imaju prigodu vidjeti među prvima na svijetu. “ „Eröffnung des Kino-Theaters“, Brioni Insel-Zeitung, 26, 3. kolovoza 1913. 
otvoreni Teatro Apollo, Cinema Corso i Teatro Fenice $)^{214}$ i Pulom, koja tada broji šest kina (u vrijeme započetoga Velikog rata, listopada i prosinca 1914., otvorena su kina Mornarički klub i Politeama Ciscutti, a zatvoreno je kino Eden), koja bi jasno posvjedočila da, kako za Rijeku, tako i za Pulu nema „zaostajanja u filmskom razvoju“.

\section{Sažetak}

Koliko je iz puljskih dnevnih i tjednih novina poznato, u Puli su od 21. studenoga 1896. do Prvoga svjetskog rata gostovala ukupno 32 putujuća kinematografa. Kinematograf Edison na Portarati otvoren je 25. travnja 1906. Njegova relativno kratka postojanost ide u prilog putujućega kinematografa, a gotovo sve ostalo u prilog stalnoga kinematografa. Prvi službeno proglašen stalni puljski kinematograf, ujedno i drugo stalno kino u današnjoj Hrvatskoj, Električno kino Internazionale (Bioscopio elettrico Internazionale) svečano je otvoreno i počelo s redovitim prikazivanjem filmova 3. lipnja 1906. Oba kinematografa, i Edison i Internazionale, ili su polustalna ili, prema umjerenijim i labavijim kriterijima, stalna kina. Internazionale, budući da nije bio putujući (otvorio ga je stanovnik Pule), postao je stalni kinematograf, unatoč samo 44 dana uzastopna prikazivanja filmova u baraci (daščari), a putujući Edison u boljim uvjetima, koji je u Puli zastao 37 dana u kinodvorani, to nije. Prema postojećim vrelima prvo stalno kino u Hrvatskoj je Salone Edison u Rijeci (13. travnja 1906.), drugo je stalno kino Internazionale u Puli (3. lipnja 1906.), treće je kino Excelsior u Puli (početak srpnja 1906.), četvrto je kino Edison u Puli (6. listopada 1906.) i peto je Pathé bioskop u Zagrebu (studeni 1906.).

Putujući su kinematografi na svojim gostovanjima i proputovanjima pored uredovnih, uobičajenih filmskih repertoara nudili i specijalizirane erotske (ili pionirske pornografske) kratke filmove po svim gradovima Europe, pa tako i u Puli koja je zbog mornaričkoga i vojnoga statusa, militantne urbanosti i poprilično slobodne seksualnosti, bila specifična pojava. Uspoređujući ranu pojavu bestidnih filmića u europskoj kinematografiji, Pula je naspram sličnih austro-ugarskih gradova prednjačila u projiciranju „pikantnih filmova”, što se pripisuje toleranciji gradskih i mornaričkih nadležnih vlasti i institucija. Takva praksa "crnih večeri” (serate nere, Herrenabende) nastavljena je i kasnije, u prvim stalnim puljskim kinematografima. Obilna ponuda tolerantnih filmova, erotskih i pornografskih sadržaja, bila je redovito na repertoaru kina Edison, trećega stalnoga puljskog kinematografa otvorenoga 6. listopada 1906., koji možemo slobodno prozvati i prvim erotskim (ili porno-erotskim) kinom u Puli (i Hrvatskoj).

Od prvoga otvorenoga (polu)stalnog kina Edison (25. travnja 1906.) do početka Prvoga svjetskoga rata (28. srpnja 1914.) u Puli je otvoreno, u samom središtu grada, deset stalnih kinematografa (posljednji je u tom razdoblju kino Eden,

214 Palinić, „O povijesti riječkih kinematografa - prvi stalni kinematografi: Salone Edison, Elektra, Progresso“, 99. 
12. siječnja 1913.) različitih kategorija, od građansko-časničkih elitnih do proletersko-vojničkih s erotsko-pornografskih programima, od kojih je pak neposredno pred Veliki rat ostalo pet djelatnih (Edison, Leopoldo, Minerva, Ideal i Eden): jedna i druga brojka (otvorenih i djelatnih kina) pokazuju i dokazuju europski trend započete ubrzane kinofikacije europskih gradova. Možemo zaključiti da je u godinama pred Veliki rat Pula bila kinematografski (kinodvoranama) i filmskim repertoarom iznimno dobro pokriven grad koji je promptno pratio gotovo sve europske (i svjetske) filmske domete preko ažurne, kvalitetne i brze distribucije filmova.

\section{Gli inizi della cinematizzazione di Pola (fino all'inizio della Grande Guerra): i primi cinematografi polesi stabili e il primo cinema erotico \\ Riassunto}

Da quanto risulta dalle pubblicazioni polesi quotidiane e settimanali, dal 21 novembre 1896 fino alla Prima guerra mondiale a Pola vennero ospitati 32 cinematografi ambulanti. Il cinematografo Edison in piazza Port'aurea fu aperto il 25 aprile 1906. La sua durata piuttosto breve andava a favore del cinematografo ambulante, mentre tutto il resto andò a favore del cinematografo stabile. Il primo cinematografo polese stabile ufficialmente dichiarato, e allo stesso tempo il secondo cinema stabile dell'odierna Croazia, il Bioscopio elettrico Internazionale, venne solennemente aperto ed iniziò con le regolari proiezioni di film il 3 giugno 1906. Entrambi i cinematografi, l'Edison e l'Internazionale, furono cinematografi semistabili o, secondo criteri più moderati e labili, cinematografi stabili. L'Internazionale, visto che non era ambulante (è stato aperto da un cittadino di Pola), diventò un cinematografo stabile, nonostante i soli 44 giorni consecutivi di proiezione di film in una baracca (capanna di legno), mentre il cinematografo ambulante Edison, in migliori condizioni e che si soffermò a Pola per 37 giorni nella sala cinematografica, non lo era diventato. Secondo le fonti esistenti, il primo cinema stabile in Croazia fu il Salone Edison di Fiume (13 aprile 1906), il secondo cinema stabile fu l'Internazionale di Pola (3 giugno 1906), il terzo l'Excelsior di Pola (inizi luglio 1906), il quarto il cinema Edison di Pola (6 ottobre 1906) e il quinto il Bioscopio Pathé di Zagabria (novembre 1906).

I cinematografi ambulanti nelle loro soste e itinerari, accanto ai repertori consueti ed ordinari, offrivano anche brevi film erotici specializzati (o film pornografici pionieristici) in tutte le città dell'Europa, e così anche a Pola, che per il suo status militare e di marina, di urbanismo militare e per la sessualità piuttosto libera, si trovava in una situazione specifica. Confrontando la prima apparizione di filmini impudenti nella cinematografia europea, in confronto con città austroungariche simili, Pola precedeva nella proiezione di "film piccanti", il che viene attribuito alla tolleranza delle istituzioni e delle autorità della marina. La prassi delle "serate nere" (Herrenabende) si è protratta anche più avanti, nei primi cinematografi stabili polesi. La ricca offerta di film tolleranti, dai contenuti erotici e pornografici, era regolarmente sul repertorio del cinema Edison, il terzo cinematografo polese stabile aperto il 6 ottobre 1906, che possiamo liberamente definire anche primo cinema erotico (o porno-erotico) di Pola (e della Croazia). 
Dal primo cinema (semi)stabile aperto, l'Edison (25 aprile 1906), fino all'inizio della Prima guerra mondiale (28 luglio 1914), a Pola sono stati aperti, in centro città, dieci cinematografi stabili (l'ultimo di questo periodo è stato il cinema Eden, 12 gennaio 1913) di varia categoria, da quelli cittadino-ufficiali d'élite fino a quelli proletario-militari con programmi erotico-pornografici, di cui, agli albori della Grande Guerra, erano rimasti cinque attivi (Edison, Leopoldo, Minerva, Ideal ed Eden): entrambi i numeri (di cinema aperti e di cinema attivi) mostrano e dimostrano la tendenza della rapida cinematizzazione iniziata nelle città europee, della nuova forma d'intrattenimento che la Pola militare adottò ed accolse calorosamente.

\section{The beginnings of cinemafication in Pula (before the Great War): the first movie- makers in Pula and the first erotic cinema}

\section{Summary}

As we could discern from Pula's daily and weekly newspapers, Pula hosted a total of 32 traveling cinemas from 21 November 1896 until World War I. Cinema Edison on Portarata was opened on 25 April 1906. Judging by its characteristics it could be considered permanent cinema were it not for the very brief period of its activity. The first officially declared permanent cinema in Pula, also the second permanent cinema on the territory of present-day Croatia was the Electric Cinema Internazionale (Bioscopio elettrico Internazionale) which opened with great pomp and began with regular screenings of films on 3 June 1906. Both cinemas, Edison and Internazionale, were either semi-permanent or, if one lowers the criteria somewhat, permanent cinemas. Since the Internazionale was opened by a resident of Pula it was considered a permanent cinema, despite only 44 days of consecutive screening of films in a barrack (a wooden shack), whereas the traveling Edison cinema was not, although it operated in better conditions and screened films in Pula's cinema for 37 days. According to existing sources, the first permanent cinema in Croatia was the Salone Edison in Rijeka (13 April 1906), the second permanent cinema was the Internazionale in Pula (3 June 1906), the third was cinema Excelsior in Pula (early July 1906), the fourth was cinema Edison in Pula (6 October 1906) and the fifth was cinema Pathé in Zagreb (November 1906).

During their visits and travels to various European cities, traveling cinemas offered, in addition to their usual repertoire of films, specialized erotic (or pioneering pornographic) short films, and this was the case in Pula as well, which, due to its naval and military status, militant urbanity and a liberal view on sexuality, was a specific phenomenon in itself. In the context of the first appearances of the so called "shameless clips" in European cinema, Pula was at the forefront with its screenings of "spicy films" compared to similar Austro-Hungarian cities, which is attributed to the greater level of tolerance by city and naval authorities. This practice of "black evenings" (serate nere, Herrenabende) had continued later in Pula's first permanent cinemas as well. An abundant supply of tolerated erotic and pornographic films was regularly featured in the repertoire of cinema Edison, the third permanent cinema in Pula opened on 6 October 1906. Indeed, one may freely call it the first erotic (or porno-erotic) cinema in Pula (and Croatia). 
From the first open (semi) permanent cinema Edison (25 April 1906) until the beginning of World War I (28 July 1914) ten permanent cinemas (the last one opened during this period was cinema Eden, 12 January 1913) were opened in Pula's city centre, and were of different categories: from elite ones for officers and the middle class, to the proletarian and military cinemas screening erotic and pornographic programs. Out of these, only five remained active right before the Great War (Edison, Leopoldo, Minerva, Ideal, and Eden): both numbers (describing open and active cinemas) show and prove a European trend of the commencement of accelerated cinemafication of European cities. This leads to the conclusion that, before the Great War, Pula was a city that enjoyed an abundance of both venues and content, with a distribution system that followed in the footsteps of major European and world centres. 